\title{
Implementation and evaluation of a new methane model within a dynamic global vegetation model: LPJ-WHyMe v1.3.1
}

\author{
R. Wania ${ }^{1, *}$, I. Ross $^{2, * *}$, and I. C. Prentice ${ }^{3, * * *}$ \\ ${ }^{1}$ Department of Earth Sciences, University of Bristol, Wills Memorial Building, Queen's Road, Bristol, BS8 1RJ, UK \\ ${ }^{2}$ School of Geographical Sciences, University of Bristol, University Road, Bristol BS8 1SS, UK \\ ${ }^{3}$ QUEST, Department of Earth Sciences, University of Bristol, Wills Memorial Building, Queen's Road, Bristol, BS8 1RJ, UK \\ * now at: School of Earth and Ocean Sciences, University of Victoria, P.O. Box 3055 STN CSC, Victoria, BC, V8W 3V6, \\ Canada \\ ** now at: Mathematics and Statistics, University of Victoria, P.O. Box 3060 STN CSC, Victoria, British Columbia V8W 3R4, \\ Canada \\ **** now at: Department of Biological Sciences, Macquarie University, Sydney, NSW 2109, Australia
}

Received: 8 December 2009 - Published in Geosci. Model Dev. Discuss.: 15 January 2010

Revised: 15 September 2010 - Accepted: 6 October 2010 - Published: 27 October 2010

\begin{abstract}
For the first time, a model that simulates methane emissions from northern peatlands is incorporated directly into a dynamic global vegetation model. The model, LPJWHyMe (LPJ Wetland Hydrology and Methane), was previously modified in order to simulate peatland hydrology, permafrost dynamics and peatland vegetation. LPJ-WHyMe simulates methane emissions using a mechanistic approach, although the use of some empirical relationships and parameters is unavoidable. The model simulates methane production, three pathways of methane transport (diffusion, plantmediated transport and ebullition) and methane oxidation. A sensitivity test was conducted to identify the most important factors influencing methane emissions, followed by a parameter fitting exercise to find the best combination of parameter values for individual sites and over all sites. A comparison of model results to observations from seven sites resulted in normalised root mean square errors (NRMSE) of 0.40 to 1.15 when using the best site parameter combinations and 0.68 to 1.42 when using the best overall parameter combination.
\end{abstract}

\section{Introduction}

Wetlands are the largest individual source of methane $\left(\mathrm{CH}_{4}\right)$ emissions and contribute $100-231 \mathrm{TgCH}_{4} \mathrm{a}^{-1}$ to a global budget of $582 \mathrm{TgCH}_{4} \mathrm{a}^{-1}$ (Denman et al., 2007). Peatlands are one type of wetland that occurs mainly in boreal

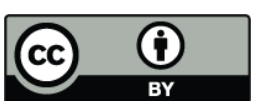

Correspondence to: R. Wania (rita@wania.net) and arctic regions, covering an area of approximately 3.0$3.2 \times 10^{6} \mathrm{~km}^{2}$ north of $40^{\circ} \mathrm{N}$ (Matthews and Fung, 1987; Aselman and Crutzen, 1989), but can also be found in tropical areas such as the Amazon, Indonesia or in tropical alpine regions (Lähteenoja et al., 2009; Page et al., 2010; Buytaert et al., 2006). The common characteristic of peatlands is that they accumulate dead organic matter to a depth of at least $30 \mathrm{~cm}$ (Maltby and Immirzi, 1993). Zhuang et al. (2004) summarised the recent literature and found that emission estimates for the pan-arctic region from eleven studies ranged from 31 to $106 \mathrm{Tg} \mathrm{CH}_{4} \mathrm{a}^{-1}$. A recent inverse modelling study allocated only $33 \pm 18 \mathrm{Tg} \mathrm{CH}_{4} \mathrm{a}^{-1}$ of total global emissions to northern wetlands ${ }^{1}$ (Chen and Prinn, 2006).

Even though present-day methane emissions from northern wetlands contribute only about $5-18 \%$ of global annual, natural and anthropogenic, methane emissions (this estimate is based on northern wetland $\mathrm{CH}_{4}$ emissions by Zhuang et al., 2004, and global $\mathrm{CH}_{4}$ emissions found in Denman et al., 2007) their relative contribution may increase under future climate change that will increase temperature and precipitation in the high latitude regions faster and more than in other regions on Earth (Meehl et al., 2007; Christensen et al., 2007). However, the processes that underlie methane emissions are complex and depend on variables such as inundation, vegetation composition, and soil temperature. These variables interact with each other, and

\footnotetext{
${ }^{1}$ Although peatlands are the dominant form of wetland in boreal and arctic regions, in the following we adhere to the terminology used in each of the sources we reference - the terms "peatland" and "wetland" thus both appear.
}

Published by Copernicus Publications on behalf of the European Geosciences Union. 
vegetation, temperature and precipitation changes in the future may have a positive feedback on wetland methane emissions if the peatland gets warmer but stays wet or becomes wetter (Johansson et al., 2006) or a negative feedback if the peatland gets drier (Moore and Knowles, 1990; Moore and Dalva, 1993).

Methane emissions to the atmosphere result from a balance between $\mathrm{CH}_{4}$ production and $\mathrm{CH}_{4}$ oxidation. Methane is produced by methanogens which are obligate anaerobic archaea, which means that they require oxygen-free environments (Vogels et al., 1988; Whitman et al., 1992). The three most important factors influencing the level of activity of methanogens and therefore $\mathrm{CH}_{4}$ production rates are the degree of anoxia, the temperature, as microbes increase their activity level up to a threshold temperature after which the activity level declines again (Svensson, 1984), and the availability of suitable carbonaceous substrate that can be utilised. Once $\mathrm{CH}_{4}$ is produced, it can be transported to the atmosphere via diffusion through the peat pore water, it can be transported through the gas-filled pore spaces (aerenchyma) of vascular plants or it can be released abruptly in the form of bubbles.

Before methane escapes to the atmosphere, it may be oxidised by methanotrophic bacteria that utilise $\mathrm{CH}_{4}$ as a carbon and energy source (Hanson and Hanson, 1996). In peatlands, methanotrophs are aerobic bacteria and their activity therefore depends on the amount of oxygen available in the peat. Oxygen can either diffuse into the peat pore water from the surface (Benstead and Lloyd, 1996) or it can be transported to the tips of the roots of vascular plants, leading to high $\mathrm{CH}_{4}$ oxidation rates (Ström et al., 2005). It is crucial to account for both oxygen transport mechanisms when modelling $\mathrm{CH}_{4}$ oxidation.

In order to study methane emissions from northern peatlands, a process-based modelling approach that takes account of interactions between vegetation, hydrology, soil thermal regime and methane-related processes is needed. In the past, methane models have been developed to estimate methane emissions from global wetlands (Cao et al., 1996; Walter and Heimann, 2000; Zhuang et al., 2004), but these models did not include the dynamic interactions between hydrology, soil temperature, vegetation and methane processes. A review of previous methane models can be found in Wania (2007). Here, we describe a new methane model that is integrated into a dynamic global vegetation model and which takes the interactions mentioned above into account. The aim of this study is to show how LPJ-WHyMe reproduces observed data when simulating $\mathrm{CH}_{4}$ emissions, without the use of site-specific input data. We discuss the uncertainties that arise and the difficulties of modelling $\mathrm{CH}_{4}$ emissions.

\section{Model description}

\subsection{LPJ-WHyMe}

LPJ-WHyMe v1.3.1 is a development of the Lund-PotsdamJena Dynamic Global Vegetation Model (LPJ) originally described by Sitch et al. (2003) and Gerten et al. (2004). LPJ is a process-based model that simulates plant physiology, carbon allocation, decomposition and hydrological fluxes. Vegetation is defined by plant functional types (PFTs) that group plants with similar traits. Each PFT is described by allocating specific parameters that distinguish one PFT from another. PFTs thus occupy different environmental niches defined by bioclimatic limits and physiological optima and compete for resources such as light and water. This competition determines the simulated vegetation composition.

LPJ-WHyMe stands for LPJ-Wetland Hydroglogy and Methane emissions and was originally described in Wania (2007). LPJ-WHyMe is a further development of LPJ-WHy, which dealt with the introduction of permafrost and peatlands into LPJ (Wania et al., 2009a). Implementing peatlands in LPJ-WHy required the addition of two new PFTs (floodtolerant $\mathrm{C}_{3}$ graminoids and Sphagnum mosses) to the already existing ten PFTs, the introduction of inundation stress for non-peatland PFTs, a slow-down in decomposition under inundation and the addition of a root exudates pool (Wania et al., 2009b). The model code is archived as supplementary material.

\subsection{Methane model structure}

The addition of a methane model did not require any changes to the rest of the model as the development of LPJ-WHy was targeted towards later inclusion of a methane model. A separate subroutine containing the methane model was simply added to the program. All of the input variables required to drive the methane model were already available. This feature distinguishes LPJ-WHyMe from other methane modelling approaches, where output from vegetation models that took no account of changes in vegetation due to inundation were used to drive methane models, neglecting the potential effects of changes in vegetation composition, reduction in net primary production and the deceleration of decomposition (e.g. Cao et al., 1996; Walter et al., 2001).

The basic concept of the methane model in LPJ-WHyMe is that a "potential carbon pool for methanogens" is created (Fig. 1). This "potential carbon pool for methanogens" is distributed over all soil layers, weighted by the root distribution (Fig. 2, top). This carbon is then split into $\mathrm{CO}_{2}$ and $\mathrm{CH}_{4}$ (Fig. 2, bottom). Based on the amount of $\mathrm{CH}_{4}$ available in each layer, the dissolved $\mathrm{CH}_{4}$ concentration and the gaseous $\mathrm{CH}_{4}$ fraction are calculated. Part of the $\mathrm{CH}_{4}$ is oxidised by oxygen that has diffused into the soil layer or has been transported through plants to the soil layer. After the oxidation is determined, dissolved methane can escape 
to the atmosphere either by diffusion or through plant tissue (aerenchyma), which is also treated as a diffusive flux. Gaseous $\mathrm{CH}_{4}$ can escape to the atmosphere by ebullition. The sum of ebullition, diffusion and plant-mediated transport represents the total $\mathrm{CH}_{4}$ flux from the soil to the atmosphere.

\subsubsection{Potential carbon pool for methanogens}

The carbon pool available for methanogenic archaea consists mainly of root exudates and easily degradable plant material, and to a much lesser extent material from the decomposition of more recalcitrant organic matter (Chanton et al., 1995). A root exudates pool was introduced into LPJ-WHy (Wania et al., 2009b) as a very labile carbon pool with a fast turnover rate $k_{\text {exu }}$. The exudates pool is directly linked to net primary production, with a fixed fraction, $f_{\mathrm{exu}}$, of net primary production being diverted into the exudates pool at each time step, which in this case is monthly. LPJ-WHyMe follows the same time step scheme as LPJ (Sitch et al., 2003), i.e. the time step varies between daily and yearly depending on the process. LPJ-WHyMe models the decomposition of aboveand belowground litter, at rate $k_{\text {litter }}$, and of the fast and the slow soil carbon pools, at rates $k_{\text {fast }}$ and $k_{\text {slow }}$, respectively (Fig. 1). Decomposition rates are a function of soil temperature $\left(R_{\mathrm{T}}\right)$, which follows Lloyd and Taylor (1994) and of soil moisture content $\left(R_{\text {moist }}\right)$ via empirically fitted relationships (Wania et al., 2009b, Sect. 2.3):

$k=k^{10} R_{\mathrm{T}} R_{\text {moist }}$,

where $k$ represents the turnover rates for exudates, litter, and the fast and slow carbon pools, and $k^{10}$ the respective decomposition rates at $10^{\circ} \mathrm{C}$ (Table 1). The moisture response, $R_{\text {moist }}$, is chosen so that the decomposition rate is reduced under inundation and its value was determined by a parameter fitting exercise (Table 4). The carbon resulting from this decomposition is classified as heterotrophic respiration in LPJ, but in LPJ-WHyMe, we treat this carbon differently at peatland and non-peatland sites. At non-peatland sites the pool behaves in exactly the same way as in LPJ and is immediately added to the atmospheric carbon dioxide flux. For peatland sites, the decomposed carbon is put into the potential carbon pool available to methanogens.

\subsubsection{Root distribution}

Carbon from the potential carbon pool for methanogens is allocated to each soil layer according to the root biomass distribution. For the hydrology processes in LPJ-WHyMe it was sufficient to split the root biomass between acrotelm and catotelm (Ingram, 1978), but for modelling the carbon cycle within the soil, a more detailed root distribution is required to allocate carbon to each $0.1 \mathrm{~m}$ thick soil layer, and also to estimate the plant-mediated transport of oxygen and methane into and out of each layer. The root distribution used in LPJWHyMe is based on data from six cores from a transition fen,

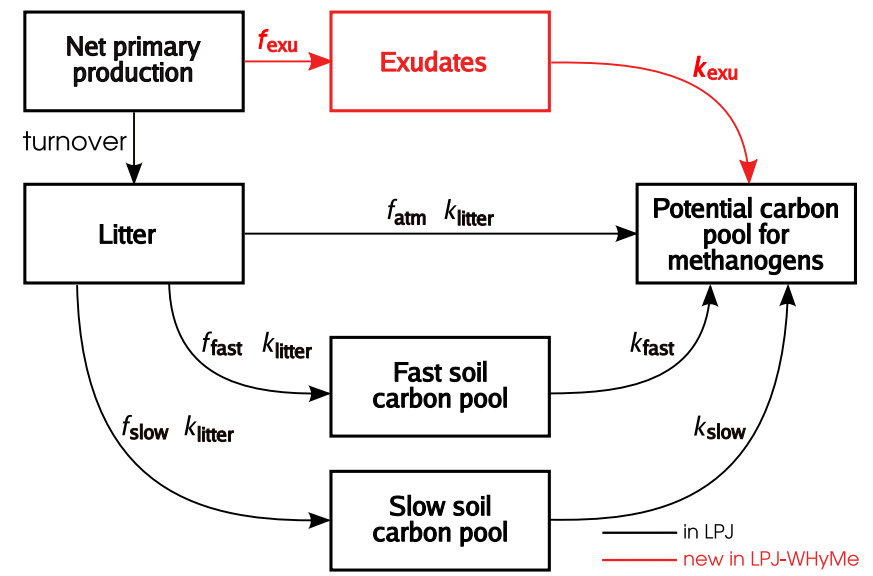

Fig. 1. Decomposition processes in LPJ-WHyMe. The turnover rate determines the fraction of net primary production converted to litter. Litter decomposes at a rate dependent on soil temperature and moisture $\left(k_{\text {litter }}\right)$. Part of the decomposed litter $\left(f_{\text {atm }}\right)$ goes directly into the potential carbon pool for methanogens; the rest is split up into the fast $\left(f_{\text {fast }}\right)$ and the slow $\left(f_{\text {slow }}=1-f_{\text {fast }}\right)$ soil carbon pools. Both soil carbon pools have their own temperature- and moisturedependent decomposition rates $\left(k_{\text {fast }}, k_{\text {slow }}\right)$. Decomposed soil carbon is added to the potential carbon pool for methanogens. The pathway highlighted in red indicates an addition in LPJ-WHyMe compared to the decomposition dynamics in LPJ. The fraction $f_{\text {exu }}$ taken from the net primary production flows into an exudates pool. The decomposition rate for exudates, $k_{\text {exu }}$, depends again on soil temperature and moisture content. Parameter values are listed in Table 1.

a blanket bog and a raised bog in Wales, UK (Gallego-Sala, 2008) and from a detailed analysis of three different species from three micro-sites in western New York, USA (Bernard and Fiala, 1986). Gallego-Sala did not separate dead from living roots and it is therefore unclear whether all roots she found in the top one metre of soil should be counted as living biomass. However, Saarinen (1996) noted that living roots of Carex rostrata Stokes can be found to a depth of $2.3 \mathrm{~m}$. The root distribution based on Gallego-Sala and Bernard and Fiala's data shows an exponential decrease of root biomass with depth which is fitted as

$f_{\text {root }}=C_{\text {root }} e^{z / \lambda_{\text {root }}}$,

where $f_{\text {root }}$ is the fraction of root biomass at the level under consideration, $z$ is the vertical coordinate, positive upwards, i.e. negative values are below the surface, $\lambda_{\text {root }}=25.17 \mathrm{~cm}$ is the decay length and $C_{\text {root }}=0.025$ is a normalisation constant to give a total root biomass of $100 \%$ within $2 \mathrm{~m}$ depth. This dependence is used for the flood-tolerant $\mathrm{C}_{3}$ graminoid plant functional type in LPJ-WHyMe. The acrotelm (i.e. the top $0.3 \mathrm{~m}$, fixed for all locations) contains around $60 \%$ of root biomass, which means that the majority of available carbon occurs in the acrotelm. When soil layers are permanently frozen throughout the year, the root biomass from the frozen layer is re-allocated upwards to the first unfrozen layer. 

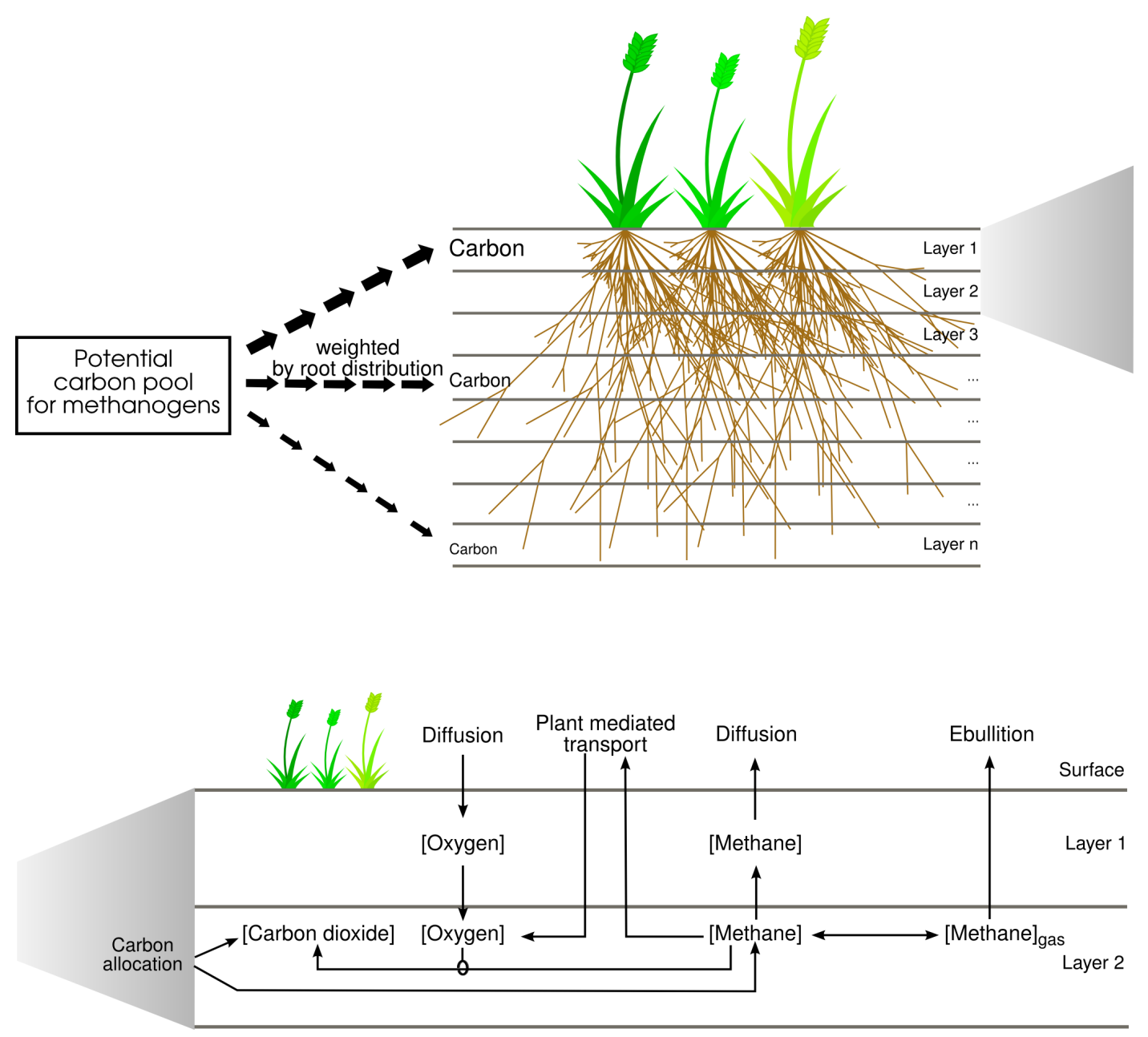

Fig. 2. Schematic representation of the LPJ-WHyMe methane model. Top: Carbon from the potential carbon pool for methanogens is allocated to soil layers according to the root distribution - more carbon is allocated to the upper layers where root density is greatest than to the bottom layers. Bottom: The carbon allocated to each layer is split into methane and carbon dioxide. Oxygen diffuses through the soil layers but is also transported directly from the atmosphere into the soil via vascular plants. The amount of oxygen available determines how much methane is oxidised and turned into carbon dioxide. Methane can diffuse to the atmosphere through overlying soil layers or it can escape directly to the atmosphere via vascular plants. The balance between methane in gaseous form, [Methane] $]_{\text {gas }}$, and methane dissolved in pore water, [Methane], is determined by the maximum solubility of methane. Any [Methane] gas will immediately be transported to the atmosphere in the form of ebullition.

Table 1. Soil carbon cycle parameter values.

\begin{tabular}{lllll}
\hline Parameter & Value & Units & Explanation & Reference \\
\hline$k_{\text {exu }}^{10}$ & 13 & $\mathrm{a}^{-1}$ & Exudate decomposition rate at $10^{\circ} \mathrm{C}$ & Based on sensitivity analysis \\
$k_{\text {litter }}^{10}$ & 0.35 & $\mathrm{a}^{-1}$ & Litter decomposition rate at $10^{\circ} \mathrm{C}$ & Sitch et al. (2003) \\
$k_{\text {fast }}^{10}$ & 0.03 & $\mathrm{a}^{-1}$ & Fast soil carbon pool decomposition rate at $10^{\circ} \mathrm{C}$ & Sitch et al. (2003) \\
$k_{\text {slow }}^{10}$ & 0.001 & $\mathrm{a}^{-1}$ & Slow soil carbon pool decomposition rate at $10^{\circ} \mathrm{C}$ & Sitch et al. (2003) \\
$f_{\text {exu }}$ & 0.175 & unitless & Fraction of NPP that is allocated to root exudates & Based on sensitivity analysis \\
$f_{\text {atm }}$ & 0.7 & unitless & Fraction of litter fraction that is respired as CO $\mathrm{CO}_{2}$ & Sitch et al. (2003) \\
$f_{\text {fast }}$ & 0.985 & unitless & Fraction of litter that enters the fast soil carbon pool & Sitch et al. (2003) \\
$f_{\text {slow }}$ & 0.015 & unitless & Fraction of litter that enters the slow soil carbon pool & Sitch et al. (2003) \\
\hline
\end{tabular}




\subsection{Methane and carbon dioxide production}

Under anaerobic conditions, decomposition rates are slower than under aerobic conditions, leading to the accumulation of organic material. The decomposed carbon is mainly turned into carbon dioxide, but a fraction is reduced to methane. The molar ratio of methane production to carbon dioxide production varies from 0.001 to 1.7 in anaerobic conditions (Segers, 1998). In a previous methane modelling approach, methane/carbon dioxide $\left(\mathrm{CH}_{4} / \mathrm{CO}_{2}\right)$ ratios of 0.0001 to 0.1 were used, depending on the water table position (Potter et al., 1996). These wide ranges make it clear that the methane/carbon dioxide ratio is difficult to predict, mainly because other electron acceptors, such as $\mathrm{NO}_{3}^{-}, \mathrm{Mn}^{4+}, \mathrm{Fe}^{3+}$ or $\mathrm{SO}_{4}^{2-}$, are reduced before methane is produced (Segers, 1998). We therefore elect to treat the methane/carbon dioxide ratio as an adjustable parameter in LPJ-WHyMe. Its value is determined through parameter fitting (Table 4). The fitted value is used for full inundation conditions and is weighted by the degree of anoxia, $\alpha$, defined as $\alpha=1-f_{\text {air }}$, where $f_{\text {air }}$ is the fraction of air in each layer. The air fraction can be derived by using the soil porosity, the volumetric fractions of mineral and organic material and the fraction of water and ice, all of which are calculated in the soil temperature subroutine (Wania et al., 2009a, Sect. 2.1.2) - a similar approach was used by Segers and Leffelaar (1996).

\subsection{Methane oxidation}

Knowing how much oxygen reaches each soil layer via diffusion and plant-mediated transport (described below), we can estimate how much methane is oxidised at each time step. Two assumptions need to be made:

1. Part of the oxygen is utilised either by the roots themselves or by non-methanotrophic microorganisms.

2. The remainder is used to oxidise methane. Stoichiometric balance requires two moles of oxygen for each mole of methane oxidised:

$$
\mathrm{CH}_{4}+2 \mathrm{O}_{2} \rightarrow \mathrm{CO}_{2}+2 \mathrm{H}_{2} \mathrm{O} \text {. }
$$

We assume that if enough oxygen is available, all of the methane is oxidised. If less oxygen is available than required, then all of the oxygen is used to oxidise methane. Oxidised methane is added to the carbon dioxide pool.

In Sect. 4.2 we test the sensitivity of methane emissions to the oxygen availability fraction parameter and adjust its value accordingly.

\subsection{Diffusion processes}

Since diffusion of gases in the soil column is governed by essentially the same equation as temperature variations, we use the same Crank-Nicolson numerical scheme as in Wania et al. (2009a, Supplementary Text S1 and Fig. S1) to solve the diffusion equation for gas transport via molecular diffusion within the soil. This is straightforward when the gas diffusivities are known. Gas diffusion processes occur more quickly than heat diffusion so require a shorter time step. The time step in the Crank-Nicolson scheme is set to one hundredth of a day (about $15 \mathrm{~min}$ ).

A more difficult aspect of modelling gas diffusion is setting up boundary conditions at the water-air interface. At the water-air boundary, gas diffusivities change by at least four orders of magnitude. Rather than applying the conventional Fick's law we chose a more robust way to calculate the gas flux $J$ from the top layer (saturated or unsaturated soil) into the overlying air layer by setting

$J=-\psi\left(C_{\text {surf }}-C_{\text {eq }}\right)$,

where $C_{\text {surf }}$ is the concentration of gas measured in the surface water, and $C_{\mathrm{eq}}$ is the equilibrium concentration of gas in the atmosphere (McGillis et al., 2000). The gas exchange coefficient, $\psi$, with units of velocity, is termed the piston velocity, which is "the height of the water that is equilibrated with the atmosphere per unit time for a given gas at a given temperature" (Cole and Caraco, 1998). A way to estimate the piston velocity $\psi$ for different gases is to relate it to the known, measured, piston velocity of a different substance, in this case $\mathrm{SF}_{6}$. We can calculate the piston velocity of another gas, $\psi_{\bullet}$, as

$\psi_{\bullet}=\psi_{600}\left(\frac{\mathrm{Sc}_{\bullet}}{600}\right)^{n}$

where

$\psi_{600}=2.07+0.215 \times U_{10}^{1.7}$

is the piston velocity (in $\mathrm{m} \mathrm{s}^{-1}$ ) of $\mathrm{SF}_{6}$ normalised to a Schmidt number ${ }^{2}$ of 600 (dependent on the wind speed in $10 \mathrm{~m}$ height, $U_{10}$, in $\mathrm{m} \mathrm{s}^{-1}$ ), Sc。 is the Schmidt number of the gas in question, and $n=-\frac{1}{2}$ (Riera et al., 1999). Using Eq. (5), the piston velocities for methane, carbon dioxide and oxygen may then be calculated.

Ideally, the wind speed would be used to force LPJWHyMe, but there are two issues here. One is that the CRU TS 2.1 climate data set that we use does not include wind speeds (Mitchell and Jones, 2005). The other issue is that one would need to know the wind speed in the peatland vegetation, not just above the vegetation canopy, as the exchange of air within the vegetation is important to drive the concentration gradients of gases. However, the water-atmosphere interface in peatlands is often found below the peat surface or within dense vegetation, which will reduce wind speed drastically. We therefore assume that the wind speed within the

\footnotetext{
${ }^{2}$ The Schmidt number, Sc, of a gas is the ratio between the coefficient of momentum diffusivity, i.e. the kinematic viscosity, and the coefficient of mass diffusivity.
} 
Table 2. Gas diffusion parameters taken from Sander (1999).

\begin{tabular}{|c|c|c|c|}
\hline Parameter & Value & Units & Description \\
\hline$k_{\mathrm{H}, \mathrm{inv}}$ & calculated & $\mathrm{L}_{\text {atm } \mathrm{mol}^{-1}}$ & Henry's coefficient \\
\hline & 298.15 & $\mathrm{~K}$ & Standard temperature \\
\hline$k_{\mathrm{H}}^{\Theta}$ for $\mathrm{CH}_{4}$ & 714.29 & $\mathrm{~L} \mathrm{~atm} \mathrm{~mol}^{-1}$ & Henry's constant at standard temperature \\
\hline for $\mathrm{CO}_{2}$ & 29.41 & $\mathrm{~L}_{\text {atm }} \mathrm{mol}^{-1}$ & Henry's constant at standard temperature \\
\hline for $\mathrm{O}_{2}$ & 769.23 & $\mathrm{Latm} \mathrm{mol}^{-1}$ & Henry's constant at standard temperature \\
\hline$C_{\mathrm{H}, \text { inv }}$ for $\mathrm{CH}_{4}$ & 1600 & $\mathrm{~K}$ & Coefficient in Henry's law \\
\hline for $\mathrm{CO}_{2}$ & 2400 & $\mathrm{~K}$ & Coefficient in Henry's law \\
\hline for $\mathrm{O}_{2}$ & 1500 & $\mathrm{~K}$ & Coefficient in Henry's law \\
\hline
\end{tabular}

peatland vegetation is negligible and choose to set the wind speed in LPJ-WHyMe to a constant value of $U_{10}=0 \mathrm{~m} \mathrm{~s}^{-1}$.

The Schmidt numbers for carbon dioxide and methane can be deduced from Jähne et al. (1987) by fitting a third-order polynomial to the observations, following Riera et al. (1999). The coefficients to estimate the Schmidt number for oxygen were taken from Wanninkhof (1992). The resulting relations give

$\mathrm{Sc}_{\mathrm{CH}_{4}}=1898-110.1 T+2.834 T^{2}-0.02791 T^{3}$,

$R^{2}=1 ; p<0.001$

$\mathrm{Sc}_{\mathrm{CO}_{2}}=1911-113.7 T+2.967 T^{2}-0.02943 T^{3}$,

$R^{2}=1 ; p<0.001$

$\mathrm{Sc}_{\mathrm{O}_{2}}=1800.6-120.1 T+3.7818 T^{2}-0.047608 T^{3}$,

where $T$ is temperature in ${ }^{\circ} \mathrm{C}$.

The concentration, $C_{\text {eq }}$, in Eq. (4), in $\mathrm{mol} \mathrm{L}^{-1}$, of a dissolved gas in equilibrium with the gas partial pressure, $p_{\text {partial }}$, above the solution can be estimated using Henry's law as $C_{\text {eq }}=p_{\text {partial }} / k_{\mathrm{H} \text {,inv }}$, where $k_{\mathrm{H} \text {,inv }}$ is Henry's coefficient in units of $\mathrm{Latm} \mathrm{mol}^{-1}$. For methane in the atmosphere, $p_{\text {partial }}=p_{\mathrm{CH}_{4}}=1.7 \times 10^{-6}$ atm. The temperature dependence of Henry's coefficient is given by

$\log k_{\mathrm{H}, \text { inv }}(T)=\log k_{\mathrm{H}}^{\Theta}-C_{\mathrm{H}, \text { inv }}\left(\frac{1}{T}-\frac{1}{T^{\Theta}}\right)$,

where $T$ is temperature in $\mathrm{K}, k_{\mathrm{H}}^{\Theta}$ is Henry's constant at standard temperature $T^{\Theta}$, and $C_{\mathrm{H} \text {,inv }}$ is a coefficient (Sander, 1999). Table 2 lists values and units for these parameters.

In the case of methane and carbon dioxide, the surface concentration $C_{\text {surf }}$ will be greater than $C_{\text {eq }}$ and $J$ will be negative, indicating flux from the soil to the atmosphere. For oxygen, the balance will be reversed and $J$ will be positive, indicating flux of gas into the soil.

\subsubsection{Diffusivity of gases}

The molecular diffusivities $D_{\mathrm{CH}_{4}}, D_{\mathrm{CO}_{2}}$ and $D_{\mathrm{O}_{2}}$ depend on temperature, the amounts of water and air in the soil and the soil porosity. We derive diffusivities in water by fitting a quadratic curve to observed diffusivities at different temperatures (Broecker and Peng, 1974), giving

$D_{\mathrm{CH}_{4} \text {, water }}=0.9798+0.02986 T+0.0004381 T^{2}$,

$R^{2}=1 ; p<0.001$,

$D_{\mathrm{CO}_{2} \text {, water }}=0.939+0.02671 T+0.0004095 T^{2}$,

$R^{2}=0.97 ; p<0.001$,

$D_{\mathrm{O}_{2} \text {, water }}=1.172+0.03443 T+0.0005048 T^{2}$,

$R^{2}=1 ; p<0.001$

where $T$ is the soil temperature in ${ }^{\circ} \mathrm{C}$ and $D_{\bullet}$, water is the diffusivity of methane, carbon dioxide and oxygen in water in $10^{-9} \mathrm{~m}^{2} \mathrm{~s}^{-1}$.

For diffusion in air, we use values given by Lerman (1979) to find the dependence of diffusivities on the temperature:

$D_{\mathrm{CH}_{4} \text {, air }}=0.1875+0.0013 T$,

$D_{\mathrm{CO}_{2} \text {, air }}=0.1325+0.0009 T$,

$D_{\mathrm{O}_{2}, \text { air }}=0.1759+0.00117 T$,

where $T$ is the soil temperature in ${ }^{\circ} \mathrm{C}$ and $D_{\bullet}$,air is the diffusivity of methane, carbon dioxide and oxygen in air in $10^{-4} \mathrm{~m}^{2} \mathrm{~s}^{-1}$.

For diffusion through soil, we also need to take account of the effect of soil porosity on the diffusivity. Our estimation of the diffusivity in porous soil, $D_{\bullet}$,soil, follows the Millington-Quirk model (Millington and Quirk, 1961). It has been shown by Iiyama and Hasegawa (2005) that this model gives better results for peat soils than the Three-PorosityModel (Moldrup et al., 2004), which has only been tested for mineral soils. Using the Millington-Quirk approach, we find

$D_{\bullet}$, soil $=\frac{\left(f_{\text {air }}\right)^{10 / 3}}{\Phi^{2}} D_{\bullet}$, air,

where $D_{\bullet}$,soil is the overall diffusivity of a gas in porous soil, $f_{\text {air }}$ is the fraction of air (or the air-filled porosity as it is termed by Millington and Quirk) and $\Phi$ is the overall porosity. $D_{\bullet}$,air is the diffusivity of the respective gas in air from Eq. (10). 
For layers where $f_{\text {air }} \leq 0.05$, the diffusivities for water are used. When $f_{\text {air }}>0.05$, the diffusivities in air, which are four orders of magnitude larger than those in water, become more important, and the values calculated in Eq. (11) are used. The final diffusivities, $D_{\bullet}$ are thus

$$
D_{\bullet}= \begin{cases}D_{\bullet}, \text { water }, & f_{\text {air }} \leq 0.05 \\ D_{\bullet} \text {,soil }, & f_{\text {air }}>0.05\end{cases}
$$

\subsection{Transport through aerenchyma}

The second pathway for methane and carbon dioxide to escape to the atmosphere and for oxygen to enter the soil is via transport through vascular plants. Some vascular plants adapt to inundation by developing aerenchyma, gas-filled tissue in roots, rhizomes, stems and leaves. As well as their main adaptive function of delivering oxygen to the roots, aerenchyma constitute direct conduits for the transport of methane and carbon dioxide from the soil to the atmosphere. Gases transported through aerenchyma either follow a concentration gradient or are actively pumped upwards. Here, we consider only the passive flux of methane and carbon dioxide through plants as it is the most dominant form of gas transport (Cronk and Fennessy, 2001). The main factors for transport through aerenchyma are thus (i) the abundance of aerenchymatous plants; (ii) the biomass of aerenchymatous plants; (iii) the phenology of aerenchymatous plants, i.e. the period roots, stems and leaves are available for gas transport; and (iv) the rooting depth of aerenchymatous plants, which determines the depth to or from which gas can be transported.

Forbs (herbaceous plants other than grasses) can have aerenchyma, but their contribution to the overall net primary production (NPP) in peatlands is generally small compared to graminoids (Weltzin et al., 2000; Camill et al., 2001). Dwarf shrubs, which may contribute more significantly to the net primary production than forbs, do not have aerenchyma. Therefore, forbs and dwarf shrubs were not included in LPJWHyMe, although we recognise that dwarf shrubs may contribute significantly to net primary production of peatlands and influence $\mathrm{CH}_{4}$ emissions via root exudates. It is therefore desirable to include dwarf shrubs into future versions of our model.

Before methane enters the plant tissue a relatively large proportion is oxidised in the highly oxic zone around the roots, where methanotrophs thrive. Rhizospheric oxidation is species dependent and can reach $100 \%$ in Juncus effusus L. and Eriophorum vaginatum L., but can be much lower in e.g. Carex rostrata with $20-40 \%$ oxidation (Ström et al., 2005).

Plant-mediated transport in LPJ-WHyMe occurs solely via the flood-tolerant $\mathrm{C}_{3}$ graminoid plant functional type, with the gas flux through vascular plants being related to the cross-sectional area of tillers ${ }^{3}$ available to transport gas. The

\footnotetext{
${ }^{3}$ Tillers are segmented stems produced at the base of many plants in the family Poaceae, with each stem possessing its own
}

mass of the tillers $m_{\text {tiller }}$ is estimated by multiplying the leaf biomass of graminoids $\left(\mathrm{b}_{\text {leaf }}^{\text {graminoid }}\right)$ by the daily phenology, $\varphi$ :

$m_{\text {tiller }}=\mathrm{b}_{\text {leaf }}^{\text {graminoid }} \varphi$.

The daily phenology $\varphi$ describes the fraction of potential leaf cover that is fully developed, e.g. deciduous plant functional types have zero leaf cover in winter and build up their leaf cover over the first few growing months. Maximum leaf cover is reached after a given number of growing degree days but can be modulated by drought stress. The tiller biomass $m_{\text {tiller }}$ is divided by the average weight of an individual tiller to obtain the number of tillers, $n_{\text {tiller. }}$. The average observed tiller biomass for Eriophorum angustifolium Honckeny and Carex aquatilis Wahlenb. in Alaska was $0.48 \mathrm{~g}$ dry matter per tiller, which corresponds to $0.22 \mathrm{~g} \mathrm{C}$ per tiller, assuming a carbon content of $45 \%$ (Schimel, 1995). The cross-sectional area of tillers, $A_{\text {tiller }}$, is derived by multiplying the area of an individual tiller, $\pi r_{\text {tiller }}^{2}$, where $r_{\text {tiller }}$ is the tiller radius, by the number of tillers, $n_{\text {tiller }}$ and the tiller porosity, $\Phi_{\text {tiller }}$ :

$A_{\text {tiller }}=n_{\text {tiller }} \Phi_{\text {tiller }} \pi r_{\text {tiller }}^{2}$.

A first estimate of the tiller radius, $r_{\text {tiller, }}$, was derived by averaging over the two widespread species Eriophorum angustifolium $(3.95 \mathrm{~mm})$ and Carex aquatilis $(1.9 \mathrm{~mm})$ (Schimel, 1995), yielding $r_{\text {tiller }}=2.9 \mathrm{~mm}$. The tiller porosity is initially set to 50\% (Cronk and Fennessy, 2001). Schimel (1995) also measured E. scheuchzeri Hoppe whose tillers contained only $0.09 \mathrm{~g}$ dry matter and whose tiller radius was $0.85 \mathrm{~mm}$. Using these values to calculate the tiller crosssectional area gives a similar value to that based on our values above ( $0.48 \mathrm{~g}$ drymatter and $2.9 \mathrm{~mm}$ radius) for the same biomass. In Sect. 4.2, the sensitivity of methane emissions to the tiller radius and porosity is tested.

Finally, each layer is allocated a fraction of the total crosssectional area of tillers according to the respective root fraction in that layer.

\subsection{Ebullition}

An upper limit on the quantity of dissolved methane is imposed, with the maximum solubility of methane at a given temperature following Yamamoto et al. (1976). The best-fit curve through Yamamoto et al.'s observations is

$S_{\mathrm{B}}=0.05708-0.001545 T+0.00002069 T^{2}$,

where $S_{\mathrm{B}}$ is the Bunsen solubility coefficient, defined as volume of gas dissolved per volume of liquid at atmospheric pressure and a given temperature. We use the ideal gas law to convert the volume of methane per volume of water into moles as

$n=p V / R T$,

two-part leaf. The usage of the word "tiller" has been expanded to the order of Poales, which includes both groups, grasses (Poaceae) and sedges (Cyperaceae), and is here used in its wider meaning. 
Table 3. Sensitivity test parameters.

\begin{tabular}{|c|c|}
\hline $\mathrm{CH}_{4} / \mathrm{CO}_{2}$ & $\begin{array}{l}\mathrm{CH}_{4} / \mathrm{CO}_{2} \text { production ratio under anaer- } \\
\text { obic conditions }\end{array}$ \\
\hline$f_{\text {oxid }}$ & $\begin{array}{l}\text { Fraction of available oxygen used for } \\
\text { methane oxidation }\end{array}$ \\
\hline$f_{\text {exu }}$ & Fraction of NPP put into exudates pool \\
\hline$k_{\mathrm{exu}}^{10}$ & Turnover rate for exudates pool \\
\hline$R_{\text {moist }}$ & $\begin{array}{l}\text { Moisture response, used to weight de- } \\
\text { composition rates for exudates, litter, } \\
\text { fast and slow carbon pools }\end{array}$ \\
\hline$\Phi_{\text {tiller }}$ & Tiller porosity \\
\hline$r_{\text {tiller }}$ & Tiller radius \\
\hline
\end{tabular}

where $p=p_{\text {atm }}+\rho g z$ is the sum of the atmospheric and hydrostatic pressures $(\mathrm{Pa})$, calculated from the density of water $(\rho)$, acceleration due to gravity $(g)$ and water height $(z), V$ is the methane volume $\left(\mathrm{m}^{3}\right), T$ is the temperature $(\mathrm{K})$, the gas constant $R$ is $8.3145 \mathrm{~m}^{3} \mathrm{~Pa} \mathrm{~K}^{-1} \mathrm{~mol}^{-1}$ and $n$ is the amount of gas (mol). Atmospheric pressure has been shown to be a trigger for ebullition (Tokida et al., 2007), but atmospheric pressure is not yet used as an input variable for LPJ-WHyMe and is therefore assigned a constant value. Any methane in excess of the maximum solubility is immediately released to the atmosphere in form of ebullition.

\section{Evaluation sites and experimental setup}

\subsection{Method for sensitivity test}

We performed an initial sensitivity experiment for seven parameters, for which there were little or no data available and for which the choice of parameter values was therefore the most uncertain. The parameters used are listed in Table 3 and the values used in each sensitivity experiment are shown in Table 4.

The sensitivity results were summarised by regressing the different methane fluxes, i.e. plant-mediated, diffusion, ebullition, and total flux, against each set of parameter values. Fluxes were normalised by the maximum of each flux type for each site to enable comparison of regression slopes between sites and flux types.

\subsection{Method for parameter fitting}

After the initial sensitivity test, we conducted a parameter fitting exercise. For the parameter fitting, we used only three values per parameter (see right hand side of Table 4), but this time, we ran the model for all of the possible 2187 different combinations in the parameter space. The monthly modelled values were compared to monthly observed values and the root mean square error (RMSE) was calculated

$\operatorname{RMSE}(m, o)=\sqrt{\frac{\sum_{i=1}^{n}\left(m_{i}-o_{i}\right)^{2}}{n}}$,

where $m$ are the modelled and $o$ the observed values; $n$ is the number of months for which we had observed values. In order to compare the statistics between sites, we normalised the RMSE (NRMSE) by the standard deviation of the observations $\mathrm{SD}_{\mathrm{o}}$.

$\mathrm{NRMSE}=\mathrm{RMSE} / \mathrm{SD}_{\mathrm{o}}$.

We used the lowest average NRMSE over all seven sites to find the best overall parameter combination and the lowest individual NRMSE to find the best site-specific parameter combination.

\subsection{Input data for LPJ-WHyMe}

Input data needed to drive LPJ-WHyMe are climate data and atmospheric $\mathrm{CO}_{2}$ concentrations. Soil texture information is not required as all grid cells for which LPJ-WHyMe is run are set to the organic soil type. For the site-by-site comparison we used the Climate Research Unit time series data CRU TS 2.1 (Mitchell and Jones, 2005), which provides monthly air temperature and cloud cover, monthly total precipitation and monthly number of wet days from 1901-2002 on a $0.5^{\circ} \times 0.5^{\circ}$ grid. The time series data were used to permit effective comparison of individual model years to observations. Atmospheric carbon dioxide concentrations for 19012002 were taken from Etheridge et al. (1996) and Keeling and Whorf (2005). For model spin-up, the first 10 years of the CRU data were repeated until 1000 years of spin-up time had been completed. Potential problems with this spin-up procedure for peatlands are discussed in Wania et al. (2009b).

\subsection{Observations}

The sites used for sensitivity study, parameter fitting and model evaluation are summarised in Table 5.

\subsubsection{Site 1: Michigan, USA}

The Buck Hollow Bog is located in southern Michigan on the Edwin S. George Reserve and is classified as an ombrotrophic peatland covered by a wet lawn of Sphagnum species and densely vegetated by Scheuchzeria palustris L., an arrow-grass (Shannon and White, 1994). Other vascular species include cranberry (Vaccinium oxycoccus L.), cottongrass (Eriophorum virginicum L.) and a leatherleaf dwarf shrub (Chamaedaphne calyculata (L.) Moench) (Shannon and White, 1994). For our model comparison, we used average methane fluxes from three micro-sites in the Buck Hollow Bog, which is characterised by a wet SphagnumS. palustris lawn. Mean annual temperature over 19712000 was $8.2^{\circ} \mathrm{C}$ and mean annual precipitation was $801 \mathrm{~mm}$ 
Table 4. Values for parameter sensitivity test and parameter adjustment.

\begin{tabular}{|c|c|c|c|c|c|c|c|c|c|}
\hline \multirow[b]{2}{*}{ Parameter } & \multirow[b]{2}{*}{ Units } & \multicolumn{4}{|c|}{ Sensitivity test } & \multicolumn{3}{|c|}{ Parameter adjustment } & \multirow{2}{*}{$\begin{array}{l}\text { Final } \\
\text { value }\end{array}$} \\
\hline & & Value 1 & Value 2 & Value 3 & Value 4 & Value 1 & Value 2 & Value 3 & \\
\hline $\mathrm{CH}_{4} / \mathrm{CO}_{2}$ & - & 0.1 & 0.2 & 0.3 & 0.4 & 0.1 & 0.2 & 0.3 & 0.1 \\
\hline$f_{\text {oxid }}$ & - & 0.3 & 0.5 & 0.7 & 0.9 & 0.5 & 0.7 & 0.9 & 0.5 \\
\hline$f_{\mathrm{exu}}$ & - & 0.05 & 0.10 & 0.15 & 0.20 & 0.05 & 0.10 & 0.15 & 0.15 \\
\hline$k_{\mathrm{exu}}^{10}$ & weeks & 7 & 13 & 26 & 39 & 7 & 13 & 26 & 13 \\
\hline$R_{\text {moist }}$ & - & 0.2 & 0.3 & 0.4 & 0.5 & 0.2 & 0.3 & 0.4 & 0.4 \\
\hline$\Phi_{\text {tiller }}$ & $\%$ & 60 & 70 & 80 & 90 & 70 & 80 & 90 & 70 \\
\hline$r_{\text {tiller }}$ & $\mathrm{mm}$ & 3 & 4 & 5 & 6 & 3 & 4 & 5 & 3 \\
\hline
\end{tabular}

Table 5. Sites used for sensitivity analysis and methane emissions evaluation.

\begin{tabular}{cllcll}
\hline No. & Site name & Country & Coordinates & Year $^{\mathrm{a}}$ & Reference \\
\hline 1 & Michigan & USA & $42^{\circ} \mathrm{N}, 84^{\circ} \mathrm{W}$ & 1991 & Shannon and White (1994) \\
2 & Minnesota & USA & $47^{\circ} \mathrm{N}, 93^{\circ} \mathrm{W}$ & 1989 & Dise et al. (1993) \\
3 & BOREAS NSA & Canada & $56^{\circ} \mathrm{N}, 99^{\circ} \mathrm{W}$ & 1996 & Bubier et al. (1998) \\
4 & Salmisuo & Finland & $63^{\circ} \mathrm{N}, 31^{\circ} \mathrm{E}$ & 1993 & Saarnio et al. (1997) \\
5 & Degerö & Sweden & $64^{\circ} \mathrm{N}, 20^{\circ} \mathrm{E}$ & 1996 & Granberg et al. (2001a) \\
6 & Abisko & Sweden & $68^{\circ} \mathrm{N}, 19^{\circ} \mathrm{E}$ & 2006 & Jackowicz-Korczyński et al. (2010) \\
7 & Ruoergai & China & $33^{\circ} \mathrm{N}, 103^{\circ} \mathrm{E}$ & 2001 & Ding et al. (2004) \\
\hline
\end{tabular}

${ }^{a}$ Year of observational data used. ${ }^{b}$ Data were digitised from Walter and Heimann (2000) as they plotted average values over three microsites.

at the nearby weather station in Lansing, Michigan (http: //www.nrcc.cornell.edu).

\subsubsection{Site 2: Minnesota, USA}

The Minnesota site is located in the US Forest Service Marcell Experimental Forest. Methane flux data from Junction Fen are used for the model-data comparison. Junction Fen is a poor fen which receives some runoff from the surrounding uplands; lacking an outlet, it is wetter than nearby peatland sites. Vegetation is dominated by a sedge (Carex oligosperma Michaux) with some arrow-grass (Scheuchzeria palustris) and cranberry (Vaccinium oxycoccus). The graminoids grow above a peat moss mat composed of Sphagnum angustifolium (C. Jens. ex Russ) C. Jens., S. capillifolium (Ehrh.) Hedw. and S. fuscum (Schimp.) Klinggr. Mean annual temperature (1961-1990) is $3{ }^{\circ} \mathrm{C}$ and mean annual precipitation is $770 \mathrm{~mm}$ (Dise, 1993).

\subsubsection{Site 3: BOREAS Northern Study Area, Canada}

The BOREAS Northern Study Site is located in central Manitoba near Thompson, and is a fen site with vegetation consisting of a variety of peat mosses (Sphagnum spp.), brown moss species (Drepandocladus exannulatus (B.S.G.) Warnst.), bogbean (Menyanthes trifoliata L.) and sedges (Carex spp.) (Joiner et al., 1999). The sparse overstorey consists of larch (Larix laricina (Du Roi) K. Koch) and bog birch
(Betula glandulosa Michx.) (Joiner et al., 1999). Methane fluxes from several micro-sites are available for the Collapse Fen and Zoltai Fen (Bubier et al., 1998) and were used in this study. Mean January temperature is $-25.0^{\circ} \mathrm{C}$ and mean July temperature is $15.7^{\circ} \mathrm{C}$; mean annual precipitation is $536 \mathrm{~mm}$ (Gower et al., 2001).

\subsubsection{Site 4: Salmisuo, Finland}

The Salmisuo mire complex is situated in eastern Finland and consists of a minerogenic, oligotrophic low-sedge Sphagnum papillosum (Lindb.) pine fen (Saarnio et al., 1997). Methane fluxes from both lawn micro-sites were used for our study. The lawn habitats are vegetated by cottongrass (Eriophorum vaginatum L.), with bog-rosemary (Andromeda polifolia L.), cranberry (Vaccinium oxycoccus) and a sedge (Carex pauciflora Lightf.). The moss layer is dominated by S. angustifolium (Russow) C. Jens., S. balticum (Russow) C. Jens., with some $S$. magellanicum Brid. and S. papillosum Lindb. (Saarnio et al., 1997). Mean annual air temperature (19712000 ) is $2.0^{\circ} \mathrm{C}$, with temperatures in January of $-11.9^{\circ} \mathrm{C}$ and in July of $15.8^{\circ} \mathrm{C}$; mean annual precipitation is $600 \mathrm{~mm}$ (Alm et al., 1999).

\subsubsection{Site 5: Degerö, Sweden}

The Degerö Stormyr is part of the Kulbäcksliden Research Park in Västerbotten county in Sweden and is about $70 \mathrm{~km}$ 
from the Gulf of Bothnia (Granberg et al., 2001b). Methane data were collected in the poor fen community which is dominated by cottongrass (Eriophorum vaginatum), cranberry (Vaccinium oxycoccus), bog-rosemary (Andromeda polifolia), arrow-grass (Scheuchzeria palustris), and a sedge (Carex limosa L.). The moss layer is dominated by Sphagnum balticum, S. majus (Russ.) C. Jens. and S. lindbergii Schimp. in Lindb. (Granberg et al., 2001a). Mean annual temperature (1961-1990) is $2.3^{\circ} \mathrm{C}$, with temperatures in January of $-12.4^{\circ} \mathrm{C}$ and in July of $14.7^{\circ} \mathrm{C}$; mean annual precipitation is $523 \mathrm{~mm}$ (Granberg et al., 2001b).

\subsubsection{Site 6: Abisko, Sweden}

The subarctic Stordalen mire is part of the Abisko research area in northern Sweden. Since 2006, methane fluxes have been recorded using an eddy-covariance flux tower and even though at the time of our research we did not have the model input data available for 2006, we decided to use the eddycovariance data as they represented one of the first such data sets. These half-hourly methane data provide a highresolution data set for this site. The flux tower covers a wet part of the palsa mire with cottongrass (Eriophorum vaginatum) and a brown moss (Drepanocladus sp.) as dominant species. The peat is underlain by permafrost with a maximum active layer depth of about $70-80 \mathrm{~cm}$ for the period 2000-2002 (Christensen et al., 2004). The mean annual air temperature (1913-2003) in Abisko, which lies $10 \mathrm{~km}$ west of Stordalen, is $-0.7^{\circ} \mathrm{C}$ with temperatures in January of $-10.9^{\circ} \mathrm{C}$ and in July of $11.6^{\circ} \mathrm{C}$; mean annual precipitation is $304 \mathrm{~mm}$ (Johansson et al., 2006).

\subsubsection{Site 7: Ruoergai, China}

The Ruoergai plateau lies on the eastern edge of the QinghaiTibetan plateau at $3400 \mathrm{~m}$ altitude. The peatland area on the Qinghai-Tibetan plateau is estimated to exceed $32000 \mathrm{~km}^{2}$, constituting $45 \%$ of China's wetlands and $75 \%$ of China's peatlands (Ding et al., 2004). Methane emissions from the Qinghai-Tibetan plateau peatlands are estimated to be around $0.45 \mathrm{Tg} \mathrm{CH}_{4} \mathrm{a}^{-1}$ (Ding et al., 2004). The peatland on the Ruoergai Plateau is dominated by two sedges, Carex meyeriana Kunth. and C. muliensis and we used the observations from these two vegetation types in our analyses. Mean annual temperature is $1{ }^{\circ} \mathrm{C}$ with a minimum temperature of $-10.7^{\circ} \mathrm{C}$ in January and maximum temperature of $10.3^{\circ} \mathrm{C}$ in July; mean annual precipitation is $650 \mathrm{~mm}$ (Ding et al., 2004).

This site is included in our study as a representative of high altitude peatlands, for comparison with the behaviour of high latitude peatlands. Although our focus here is on the high latitudes, we can thus provide an initial evaluation of the suitability of LPJ-WHyMe for the simulation of methane fluxes from high altitude environments at low latitudes.
Note: The CRU mean annual temperature for the grid cell corresponding to the Ruoergai study site, with coordinates $32^{\circ} 47^{\prime} \mathrm{N}, 102^{\circ} 32^{\prime} \mathrm{E}$, deviated from the observed climate by $+3{ }^{\circ} \mathrm{C}$. We suspect that this is due to the steep topography in this region, where a small error in location may lead to a large change in climate. To compensate for this effect, we therefore use the adjacent grid cell to the west, which has a mean annual temperature of $1.4^{\circ} \mathrm{C}$ (minimum $-10.5^{\circ} \mathrm{C}$, maximum $11.4^{\circ} \mathrm{C}$, for the period $1998-2002$ ). These values are similar to the observed climate and are expected to provide a better fit of model results to observed methane fluxes.

\section{Results}

\subsection{Vegetation and land surface processes}

Net primary production, soil temperature and water table position simulated by LPJ-WHyMe (Fig. 3) are presented to provide a framework for the interpretation of methane emission results. Wania et al. (2009a) deals with the evaluation of the simulation of soil temperature and water table position in LPJ-WHyMe in detail - we present these results here to provide context for the ensuing discussion of methane flux results. The purpose of the development of LPJ-WHyMe is to create a model that is applicable on a circumpolar scale without the need for additional input data, such as vegetation composition or biomass estimates that are usually not available for remote areas. Therefore vegetation composition was allowed to evolve freely. Total net primary production for the seven test sites ranges from 272 to $479 \mathrm{gC} \mathrm{m}^{-2} \mathrm{a}^{-1}$ (Table 6), which includes both aboveground and belowground net primary production. The percentage of Sphagnum moss net primary production ranges from $0-35 \%$ of total net primary production, which means that flood-tolerant $\mathrm{C}_{3}$ graminoids are the dominant PFT in terms of net primary production. A discussion of LPJ-WHyMe's simulated net primary production values can be found in Wania et al. (2009b).

Permafrost occurs at the BOREAS, Abisko and Ruoergai sites, diagnosed by soil temperatures in deeper soil layers that never rise above $0{ }^{\circ} \mathrm{C}$ (Fig. 3). Since the BOREAS and Abisko sites lie in the zone of discontinuous permafrost, it is not unrealistic for LPJ-WHyMe to simulate permafrost conditions.

Sites 2-5 (Minnesota, BOREAS, Salmisuo and Degerö) show a clear snow melt peak at the beginning of the growing season resulting in the highest water table positions of that particular year. The Abisko site does not show a clear snow melt peak due to continously high water table positions and the Ruoergai site accumulates less than $10 \mathrm{~cm}$ of snow over the winter, so there is little melt water available to contribute to increasing water table positions. 
Table 6. Simulated net primary production (NPP), including above- and belowground production, for the seven test sites. Net primary production is shown for the flood-tolerant $\mathrm{C}_{3}$ graminoid PFT (ftG), Sphagnum moss PFT (SM) and totalled over all plant functional types (all values in $\mathrm{g} \mathrm{C} \mathrm{m}^{-2} \mathrm{a}^{-1}$ ). Note that the total net primary production equals the sum of the $\mathrm{C}_{3}$ graminoid PFT and Sphagnum PFT as no other plant functional types contributed to the net primary production at these sites. The fraction of net primary production due to flood-tolerant $\mathrm{C}_{3}$ graminoids ( $\mathrm{ftG} \%$ ) is also shown.

\begin{tabular}{lccccccc}
\hline & Michigan & Minnesota & BOREAS & Salmisuo & Degerö & Abisko & Ruoergai \\
\hline $\mathrm{ftG}$ & 269 & 327 & 262 & 320 & 291 & 304 & 260 \\
$\mathrm{SM}$ & 3 & 74 & 72 & 159 & 153 & 0 & 92 \\
$\mathrm{Total}$ & 272 & 401 & 334 & 479 & 445 & 304 & 352 \\
$\mathrm{ftG} \%$ & 99 & 82 & 78 & 67 & 65 & 100 & 74 \\
\hline
\end{tabular}
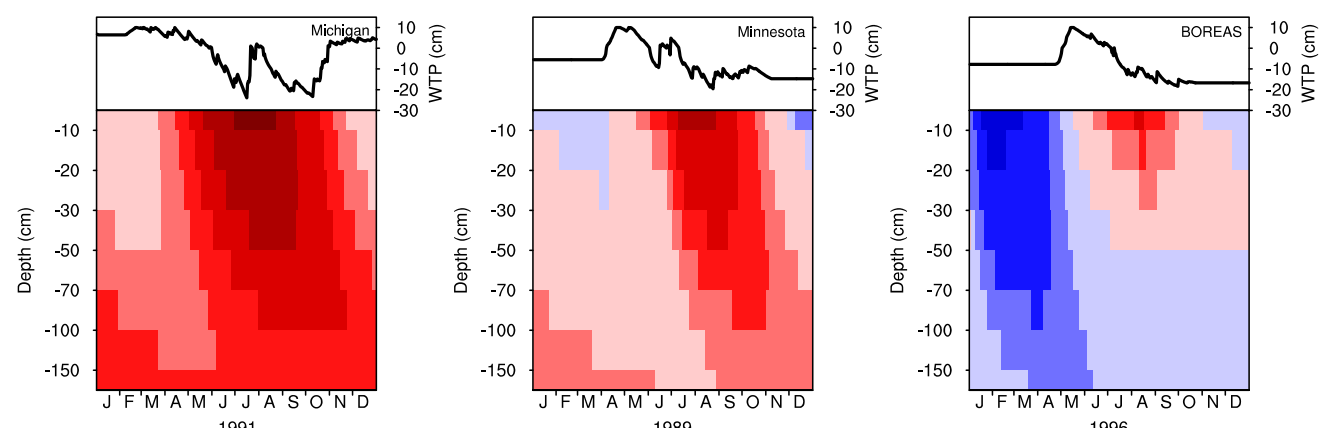

Water table and soil temperature
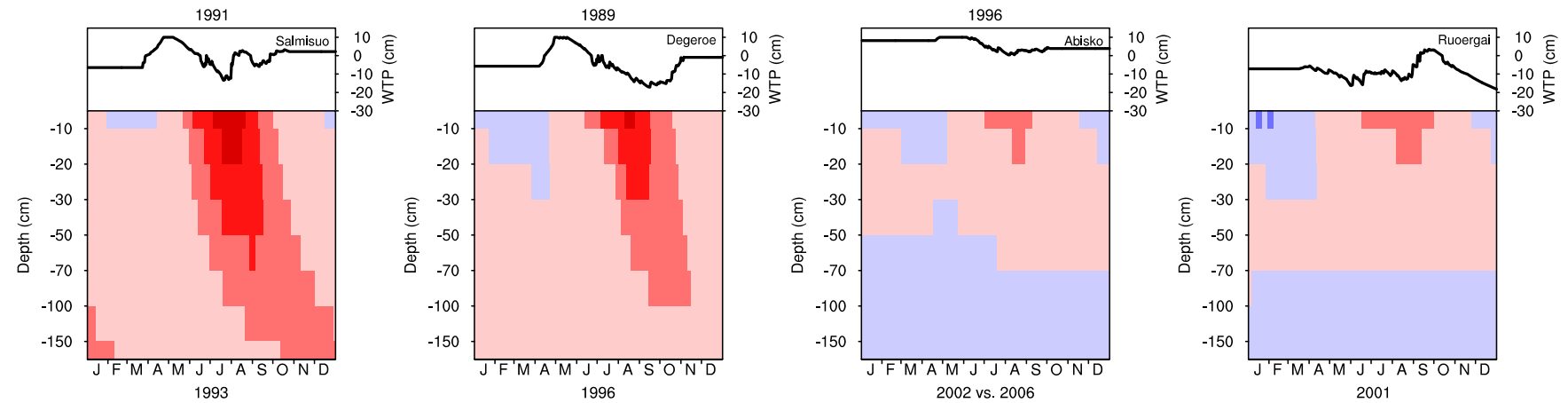

Fig. 3. Simulated water table position (line graphs) and soil temperature (contours) at the seven test sites.

\subsection{Sensitivity test}

The impact of seven parameters on total methane flux as well as plant-mediated transport, diffusive flux and ebullition was tested by using four levels for each parameter. Results are summarised in Fig. 4. The parameters $\mathrm{CH}_{4} / \mathrm{CO}_{2}, f_{\text {oxid }}$, $f_{\mathrm{exu}}, k_{\mathrm{exu}}^{10}$ and $R_{\text {moist }}$ influence the production or oxidation of methane, while $\Phi_{\text {tiller }}$ and $r_{\text {tiller }}$ affect methane transport pathways. Values used for each parameter are listed in Table 4 .

\subsubsection{Methane/carbon dioxide ratio, $\mathrm{CH}_{4} / \mathrm{CO}_{2}$}

The results in Fig. 4 show that the most important parameter - indicated by the darkest colours - for all fluxes is the ratio of methane to carbon dioxide production under anaerobic conditions, $\mathrm{CH}_{4} / \mathrm{CO}_{2}$. As expected, higher $\mathrm{CH}_{4} / \mathrm{CO}_{2}$ leads to greater methane emissions as more of the carbon is channeled into the $\mathrm{CH}_{4}$ pool. Plant-mediated transport increases marginally less (lighter red colour) than the other fluxes, most likely because the capacity for plant-mediated transport is limited by the availability of tillers and can saturate, so that additional methane escapes via ebullition and diffusion.

\subsubsection{Oxidation fraction, $f_{\text {oxid }}$}

The greater the fraction of available oxygen used for the oxidation of methane, $f_{\text {oxid }}$, the less methane is emitted. Diffusion decreases slightly more than the other two fluxes because the diffusive flux cannot circumvent the top layer into which oxygen diffuses. However, small reductions are seen in all of the fluxes since oxygen is also transported down to deeper soil layers via aerenchyma, where it 

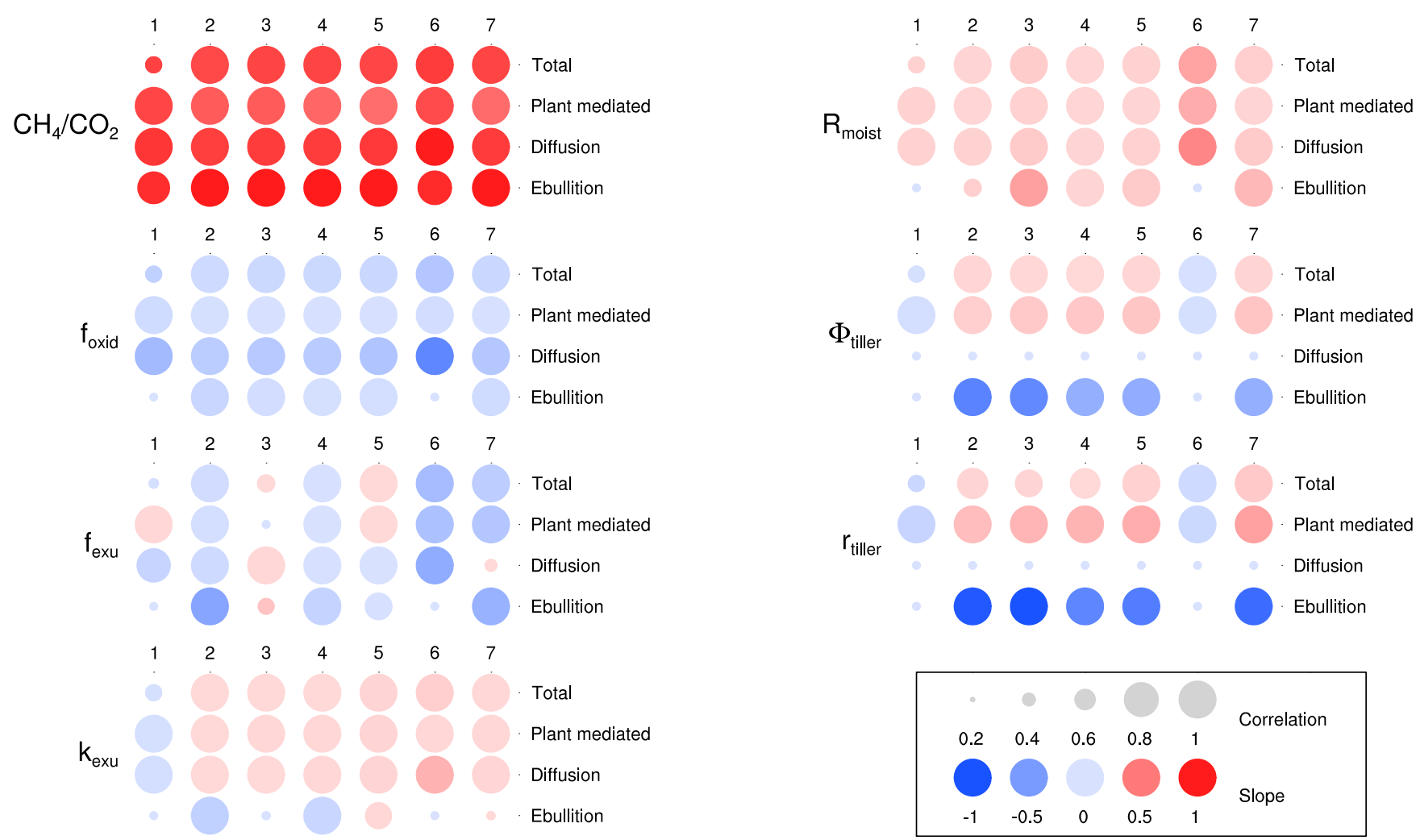

Fig. 4. Schematic summary of the sensitivity test. Numeric labels correspond to the site numbers in Table 5 and an explanation of the acronyms for the parameters can be found in Table 3. Correlations between parameter variations and changes in methane fluxes are expressed by coloured circles of different sizes. The size of the circle represents the correlation coefficient $r^{2}$, with bigger circles showing higher $r^{2}$ values. The colours represent the regression slope, with darker colours indicating steeper slopes and hence a strong increase (red) or decrease (blue) in methane fluxes with increasing parameter value (slope values were capped at -1 and 1 ). The parameters $\Phi_{\text {tiller }}$ and $r_{\text {tiller }}$ influence the transport pathways and all others affect production or oxidation of methane.

leads to decreased methane concentrations and affects plantmediated transport and ebullition.

\subsubsection{Fraction of exudates, $f_{\text {exu }}$}

The fraction of exudates has a small effect in both directions. Both increases and decreases in methane fluxes are seen at sites 1,5 and 7, while sites 2, 3, 4 and 6 show slopes in only one direction with increasing $f_{\text {exu }}$ (note that we count the small blue dot for site 3 and plant-mediated transport as having a low correlation value and no notable slope). The effect of increasing $f_{\text {exu }}$ is complex: higher $f_{\text {exu }}$ values lead to more exudates being available for methane production, but $f_{\text {exu }}$ is subtracted from the net primary production, which can lead to an overall negative effect on methane emissions due to a reduction in leaf biomass, which is used to calculate tiller biomass (Eq. 13).

\subsubsection{Exudate turnover rate, $\boldsymbol{k}_{\mathrm{exu}}^{10}$}

Changes in the decomposition rate of exudates, $k_{\mathrm{exu}}^{10}$, affected site 1 in a negative way and the other sites in a mainly positive way. Ebullition was the flux least affected by changes in $k_{\mathrm{exu}}^{10}$, most likely because ebullition was low to start with.

\subsubsection{Moisture response, $R_{\text {moist }}$}

The moisture response, $R_{\text {moist }}$, used to calculate decomposition rates, had a positive effect on almost all methane fluxes: only ebullition for two sites remained the same (small light blue dots). Higher $R_{\text {moist }}$ values led to faster turnover times (Eq. 1), which increased the availability of carbon and enhanced $\mathrm{CH}_{4}$ emissions slightly.

\subsubsection{Tiller porosity, $\Phi_{\text {tiller }}$}

The tiller porosity is used in Eq. (14) and influences the area available for plant-mediated transport. Higher porosity values lead to mixed results due to its dual effect. It increases 

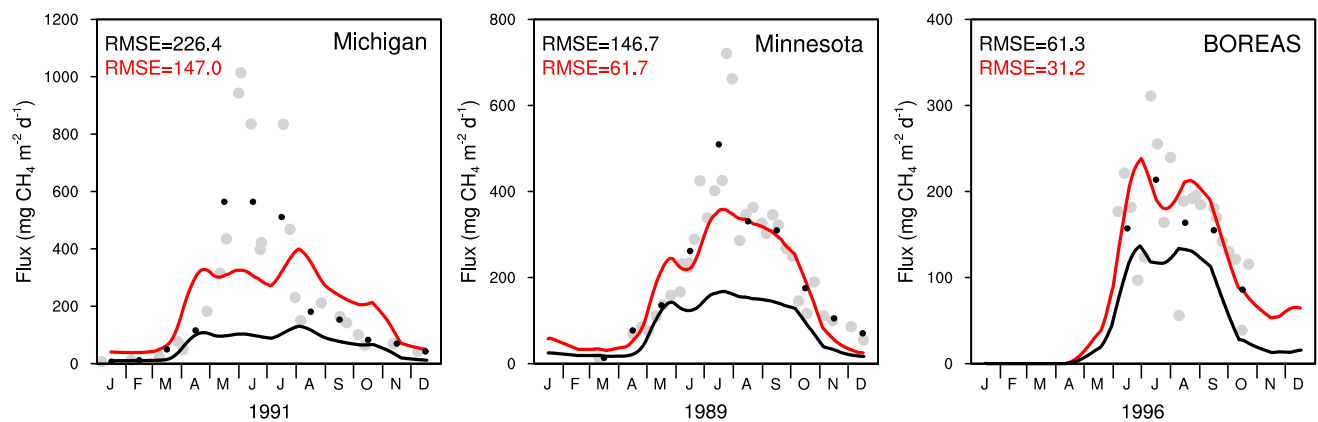

\section{Total Emissions}
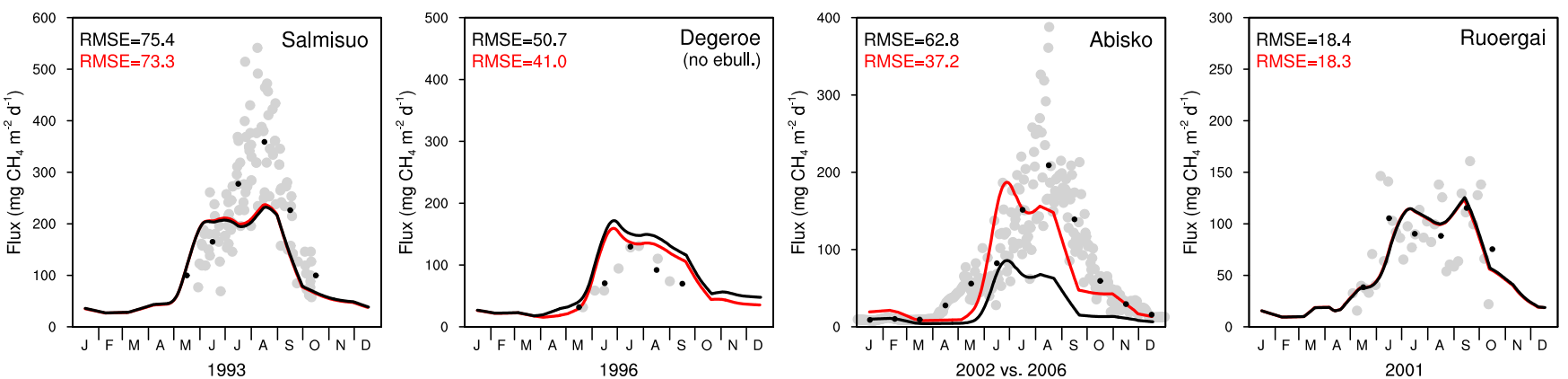

Fig. 5. Modelled methane emissions compared to observations for seven sites. Model results are plotted as 30-day running mean for the best overall parameter combination (black line) and for the best site-specific parameter combination (red line); the respective RMSE values $\left(\mathrm{mg} \mathrm{CH}_{4} \mathrm{~m}^{-2} \mathrm{~d}^{-1}\right)$ are given in the top left corner of each box and follow the same colour code. Observations are plotted as daily values (grey dots) and as monthly averages of daily values (black dots). Note that the scale of y-axes varies between plots.

the escape pathway for methane via plant-mediated transport, but at the same time it enhances the oxygen transport into the soil. At five sites, higher $\Phi_{\text {tiller }}$ values increase the plantmediated flux while at the same time decreasing the ebullition flux. The overall effect is positive for four out of the five sites as shown by the total fluxes. Diffusion is not affected by this nor the next parameter.

\subsubsection{Tiller radius, $r_{\text {tiller }}$}

The tiller radius is used in the same equation as the tiller porosity, i.e. Eq. (14). A larger tiller radius has a similar effect on plant-mediated transport to tiller porosity as it increases gas diffusion through plants. The sensitivity test shows that the range of parameter values chosen for the tiller radius (see Table 4) influences the balance between plant-mediated transport and ebullition slightly more than the tiller porosity. Plant-mediated transport shows a somewhat stronger increase and ebullition a stronger decrease when tiller radius is varied than when the tiller porosity is varied. The effect on the total methane flux is weaker as indicated by the lower correlation for sites $2-4$ but is similar to the impact of varying tiller porosity.

\subsection{Parameter fitting}

Modelled and observed methane emissions for seven sites are shown in Fig. 5. As the main purpose of the development of
LPJ-WHyMe is to simulate circumpolar methane emissions it is necessary to choose a single set of model parameters that can be applied to all grid cells. We used the parameter fitting exercise to determine which parameter set leads to the smallest overall error expressed as RMSE (black lines in Fig. 5), but we also wanted to show how much better the model can perform when tuned to individual sites (red lines in Fig. 5). The results shown in Fig. 5 are based on the parameter values and the statistics listed in Table 7. Figure 6 and Table 8 give details about the contribution of individual fluxes given the best overall parameter combination.

\subsubsection{Michigan}

LPJ-WHyMe cannot replicate the observed methane fluxes at the Michigan study site. The RMSE is, at $226.4 \mathrm{mg} \mathrm{CH}_{4} \mathrm{~m}^{-2} \mathrm{~d}^{-1}$, the largest of all the sites. Using the site-specific parameter values increases the methane flux, causing a reduction in the RMSE to $147.0 \mathrm{mg} \mathrm{CH}_{4} \mathrm{~m}^{-2} \mathrm{~d}^{-1}$, which is still the highest value of all seven sites. The increase in methane flux from the best-overall parameter values to the site-specific ones is achieved by increasing the parameters $\mathrm{CH}_{4} / \mathrm{CO}_{2}, f_{\text {oxid }}$ and $k_{\mathrm{exu}}^{10}$ (Table 7) indicating an underestimation of methane production when using the overall best parameter combination.

The estimated observed plant-mediated flux for the dominant species Scheuchzeria palustris at this site 
Table 7. Parameter fitting summary. The entries in the top half of the table indicate parameter values that lead to the lowest average NRMSE over all sites and the parameter values used to achieve the lowest NRMSE for each particular site. The lower half of the table gives the NRMSE values for each site given the parameter combination above. The $2187\left(3^{7}\right)$ combinations used for each site were ranked based on the best average NRMSE over all sites and this rank is listed in the bottom row. The rank can be used as an indication of how close the fit of the best overall parameter set is compared to the fit of the site-specific parameter set.

\begin{tabular}{lcccccccc}
\hline Parameter & All sites & Site 1 & Site 2 & Site 3 & Site 4 & Site 5 & Site 6 & Site 7 \\
\hline $\mathrm{CH}_{4} / \mathrm{CO}_{2}$ & 0.1 & 0.3 & 0.2 & 0.2 & 0.1 & 0.1 & 0.2 & 0.1 \\
$f_{\text {oxid }}$ & 0.5 & 0.9 & 0.5 & 0.9 & 0.5 & 0.9 & 0.5 & 0.5 \\
$f_{\text {exu }}$ & 0.15 & 0.15 & 0.15 & 0.10 & 0.15 & 0.15 & 0.15 & 0.15 \\
$k_{\text {exu }}^{10}$ & 13 & 26 & 26 & 7 & 26 & 7 & 26 & 7 \\
$R_{\text {moist }}$ & 0.4 & 0.4 & 0.4 & 0.2 & 0.4 & 0.2 & 0.4 & 0.4 \\
$\Phi_{\text {tiller }}$ & 70 & 70 & 70 & 70 & 70 & 70 & 70 & 70 \\
$r_{\text {tiller }}$ & 3 & 3 & 3 & 3 & 3 & 3 & 3 & 3 \\
NRMSE Site1 & 1.04 & 0.67 & 0.79 & 0.83 & 1.04 & 1.07 & 0.79 & 1.04 \\
NRMSE Site2 & 0.96 & 0.58 & 0.40 & 0.46 & 0.96 & 1.01 & 0.40 & 0.96 \\
NRMSE Site3 & 1.35 & 2.85 & 1.10 & 0.69 & 1.33 & 1.59 & 1.10 & 1.36 \\
NRMSE Site4 & 0.73 & 2.90 & 1.27 & 1.03 & 0.71 & 0.84 & 1.27 & 0.75 \\
NRMSE Site5 & 1.42 & 5.42 & 3.83 & 3.22 & 1.47 & 1.15 & 3.83 & 1.39 \\
NRMSE Site6 & 0.95 & 0.64 & 0.56 & 0.74 & 0.92 & 1.10 & 0.56 & 0.96 \\
NRMSE Site7 & 0.68 & 6.31 & 2.96 & 2.38 & 0.70 & 0.85 & 2.96 & 0.68 \\
& & & & & & & & \\
Average NRMSE & 1.02 & 2.77 & 1.56 & 1.34 & 1.02 & 1.09 & 1.56 & 1.02 \\
Rank (NRMSE) & 1 & 1609 & 900 & 733 & 2 & 186 & 900 & 3 \\
\hline
\end{tabular}

Table 8. Simulated plant mediated transport, diffusion, ebullition and total $\mathrm{CH}_{4}$ fluxes $\left(\mathrm{g} \mathrm{CH}_{4} \mathrm{~m}^{-2} \mathrm{a}^{-1}\right)$ from seven test sites using the overall best parameter set. Percentage values in parentheses list the contribution of each flux type to the total flux.

\begin{tabular}{clrlrlllr}
\hline No. & Site Name & \multicolumn{2}{c}{ Plant } & \multicolumn{2}{c}{ Diffusion } & \multicolumn{2}{c}{ Ebullition } & Total \\
\hline 1 & Michigan & 16.93 & $(75.6 \%)$ & 5.45 & $(24.4 \%)$ & 0.00 & $(0.0 \%)$ & 22.38 \\
2 & Minnesota & 21.88 & $(76.7 \%)$ & 6.53 & $(22.9 \%)$ & 0.11 & $(0.4 \%)$ & 28.54 \\
3 & BOREAS & 11.49 & $(69.9 \%)$ & 4.80 & $(29.2 \%)$ & 0.14 & $(0.9 \%)$ & 16.43 \\
4 & Salmisuo & 24.51 & $(67.8 \%)$ & 11.17 & $(30.9 \%)$ & 0.49 & $(1.4 \%)$ & 36.16 \\
5 & Degerö & 19.58 & $(74.3 \%)$ & 6.76 & $(25.7 \%)$ & 0.22 & $(0.8 \%)$ & 26.35 \\
6 & Abisko & 7.52 & $(84.5 \%)$ & 1.38 & $(15.5 \%)$ & 0.00 & $(0.0 \%)$ & 8.90 \\
7 & Ruoergai & 13.22 & $(70.8 \%)$ & 5.38 & $(28.8 \%)$ & 0.06 & $(0.3 \%)$ & 18.66 \\
\hline
\end{tabular}

is about $250 \mathrm{mgCH}_{4} \mathrm{~m}^{-2} \mathrm{~d}^{-1}$ (Shannon et al., 1996), which is twice the value simulated by LPJ-WHyMe (126.2 $\mathrm{mg} \mathrm{CH}_{4} \mathrm{~m}^{-2} \mathrm{~d}^{-1}$ ). Shannon et al. (1996) estimated the contribution of $S$. palustris to total methane emissions to be between 64 and $90 \%$ and LPJ-WHyMe simulates $75.6 \%$ plant-mediated emissions (Table 8). Modelled annual methane flux is $22.38 \mathrm{~g} \mathrm{CH}_{4} \mathrm{~m}^{-2} \mathrm{a}^{-1}$ which is in the range of the observations for the Big Cassandra Bog (0.2 to $\left.47.3 \mathrm{~g} \mathrm{CH}_{4} \mathrm{~m}^{-2} \mathrm{a}^{-1}\right)$ but lower than for Buck Hollow Bog (66.9 to $76.3 \mathrm{~g} \mathrm{CH}_{4} \mathrm{~m}^{-2} \mathrm{a}^{-1}$ ) (Shannon and White, 1994). Ebullition at this site is zero, as is the case for the Abisko site, due to the vegetation cover. The Michigan and the Abisko sites are the ones for which LPJ-WHyMe models almost exclusively flood-tolerant graminoids as vegetation cover (Table 6). This means that in proportion to the net primary production, there is more potential for plant-mediated transport than at other sites and therefore less $\mathrm{CH}_{4}$ is available for ebullition.

\subsubsection{Minnesota}

The Minnesota site shows good agreement between observations and simulated methane fluxes in all months but July for the site-specific parameter set (Fig. 5). The RMSE error for the site-specific combination is $61.7 \mathrm{mg} \mathrm{CH}_{4} \mathrm{~m}^{-2} \mathrm{~d}^{-1}$, but it is more than twice as high for the overall best parameter combination. The methane fluxes are lower for the overall best parameter set and total $28.54 \mathrm{~g} \mathrm{CH}_{4} \mathrm{~m}^{-2} \mathrm{a}^{-1}$ (Table 8), which is slightly less than half of the maximum observed estimate for this site of $65.7 \mathrm{~g} \mathrm{CH}_{4} \mathrm{~m}^{-2} \mathrm{a}^{-1}$ (Dise, 1993), but close to the mean value over four micro-habitats (Table 9). The balance between plant-mediated flux, diffusion 
Table 9. Modelled total $\mathrm{CH}_{4}$ fluxes $\left(\mathrm{g} \mathrm{CH}_{4} \mathrm{~m}^{-2}\right)$ from seven test sites for the same time period as the observations taken from the references listed in Table 5 using the overall best parameter set.

\begin{tabular}{clrrl}
\hline No. & Site Name & Modelled & Observed & Notes on observations \\
\hline 1 & Michigan & 22.38 & $0.2-47.3$ & Big Cassandra Bog, 1991 \\
& & & $66.9-76.3$ & Buck Hollow Bog, 1991 \\
2 & Minnesota & 28.06 & 31.5 & mean over four micro habitats, April 1989-April 1990 \\
3 & BOREAS & 14.5 & 23.2 & 4 mean over two fens, June - 21 October 1996 \\
4 & Salmisuo & 24.65 & $9.6-40$ & 1 June - 17 October 1993 \\
5 & Degerö & 18.66 & $16,13,18$ & Ebullition excluded, May-September 1995, 1996, 1997 \\
6 & Abisko & 8.90 & 24.5 and 29.5 & Gap-filled eddy-covariance data, 2006 and 2007 \\
7 & Ruoergai & 14.20 & $8.2-15.3$ & 165 days between May and October 2001 \\
\hline
\end{tabular}

and ebullition is very similar to the Michigan site (Table 8 and Fig. 6).

\subsubsection{BOREAS}

The site-specific parameter combination deviates from the overall best parameter set in five of the seven varied parameters (Table 7) and achieves an RMSE that is half of that of the overall best parameter combination (Fig. 5). We only had five months of observations available for this site, which should be kept in mind when comparing the site-specific and the overall best parameter sets. The site-specific parameter set continues to show relatively high methane emissions into the winter months.

For the BOREAS site, plant-mediated transport was the most important flux with $69.9 \%$ of total emissions, while diffusion contributed $29.2 \%$ and ebullition the remainder (Table 8). Figure 6 shows that diffusion is responsible for $\mathrm{CH}_{4}$ fluxes in the shoulder season, mainly in spring before plant growth has started. Total simulated methane emissions for the observational season were $14.5 \mathrm{~g} \mathrm{CH}_{4} \mathrm{~m}^{-2}$ season $^{-1}$, which underestimates the observed emissions $23.2 \mathrm{~g} \mathrm{CH}_{4} \mathrm{~m}^{-2}$ season ${ }^{-1}$ (Table 9).

\subsubsection{Salmisuo}

The Salmisuo site is one of the two sites for which the site-specific parameter set and the best overall paramter set were almost identical (Table 7) and the RMSE difference between the two parameter sets was minimal (Fig. 5). Since the RMSE for the Salmisuo site was still 73$75 \mathrm{mg} \mathrm{CH}_{4} \mathrm{~m}^{-2} \mathrm{~d}^{-1}$, we assume that further fine-tuning of the parameters, i.e. choosing values between the ones we used, could achieve better results for the site-specific case.

Total annual simulated emissions were $36.16 \mathrm{~g} \mathrm{CH}_{4} \mathrm{~m}^{-2} \mathrm{a}^{-1}$. Observations for the period 1 June to 17 October 1993 estimate the averaged fluxes over the different microsites including lawns, flarks and hummocks to be $27.2 \mathrm{~g} \mathrm{CH}_{4} \mathrm{~m}^{-2} \mathrm{a}^{-1}$ (Saarnio et al., 1997). The LPJ-WHyMe emissions for the same period are $24.65 \mathrm{~g} \mathrm{CH}_{4} \mathrm{~m}^{-2} \mathrm{a}^{-1}$, within the observed range (Table 9).
A recent detailed comparison of the Salmisuo observations to LPJ-WHyMe results expands this work to multiple years and discusses successes and failures of the simulations (Forbrich et al., 2010).

\subsubsection{Degerö}

Both parameter combinations show an overestimation of $\mathrm{CH}_{4}$ fluxes in three out of the five available months (Fig. 5) for the Degerö site. Since we knew that the measurements at this site excluded ebullition fluxes (Granberg et al., 2001a,b), we included only plant-mediated flux and diffusion in the model results in Fig. 5. Figure 6 shows that plant-mediated fluxes alone fit the observations better than the total flux. Total annual $\mathrm{CH}_{4}$ flux is $26.35 \mathrm{~g} \mathrm{CH}_{4} \mathrm{~m}^{-2} \mathrm{a}^{-1}$ of which $74.3 \%$ is emitted via plants (Table 8 ). Another modelling study showed a contribution of plant-mediated transport of 52-94\% (Granberg et al., 2001a). The observed range of methane emissions for May to September for the years 19951997 is 16,13 and $18 \mathrm{~g} \mathrm{CH}_{4} \mathrm{~m}^{-2}$, respectively (Granberg et al., 2001a). The simulated annual plant-mediated and diffusive flux in our study is $26.35 \mathrm{~g} \mathrm{CH}_{4} \mathrm{~m}^{-2} \mathrm{a}^{-1}$ in 1996 and $18.66 \mathrm{~g} \mathrm{CH}_{4} \mathrm{~m}^{-2}$ for May to September 1996 (Table 9).

\subsubsection{Abisko}

The Stordalen mire in the Abisko region is the only site for which we used data from an eddy-covariance flux tower. The site-specific parameter set achieved good results, but the overall best parameter set increased the RMSE from 37.2 to $62.8 \mathrm{mg} \mathrm{CH}_{4} \mathrm{~m}^{-2} \mathrm{~d}^{-1}$ (Fig. 5). Even with the site-specific parameter set, there is a timing problem with the $\mathrm{CH}_{4}$ emissions. The observed $\mathrm{CH}_{4}$ flux starts in April, whereas the simulated flux switches on only in late May. The modelled fluxes also decrease too early in the season. The late start of the emissions points towards a potential problem in the modelled soil thermal regime as Fig. 3 shows that the top soil layer is still between -4 and $0^{\circ} \mathrm{C}$ in May, when observed $\mathrm{CH}_{4}$ emissions have been going for two months already.

The rather abrupt decrease of $\mathrm{CH}_{4}$ emissions in August is due to the way LPJ models leaf phenology. When the air 

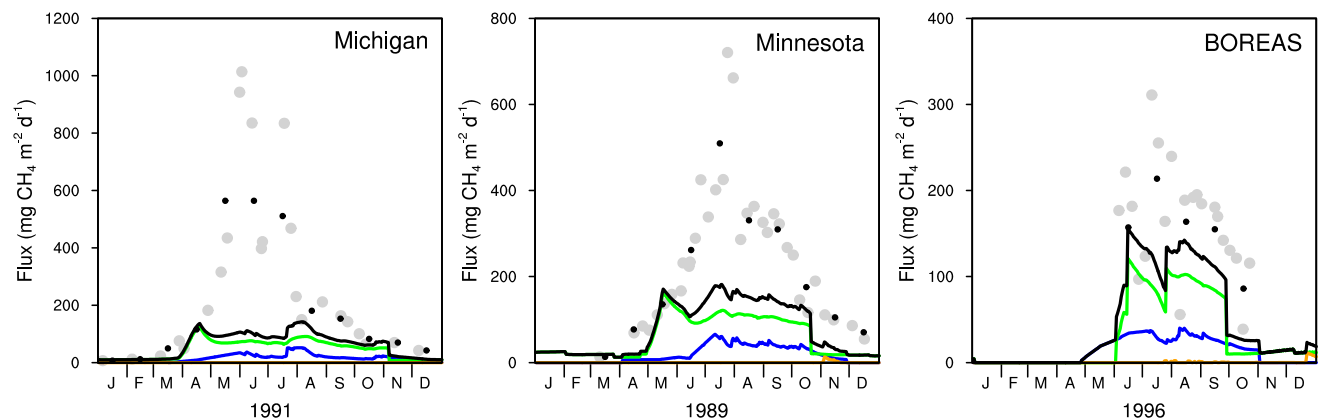

\section{Methane fluxes}
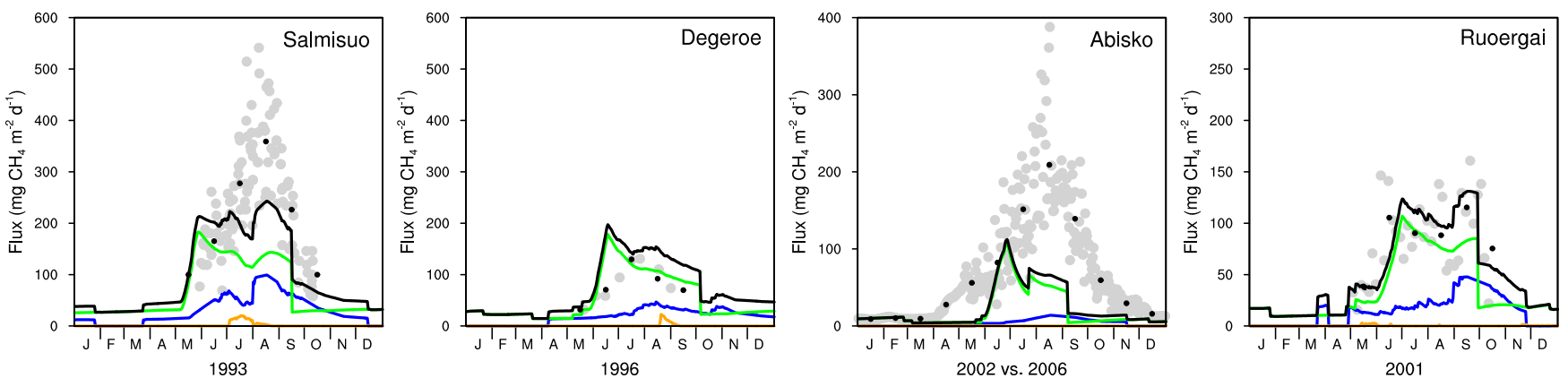

Fig. 6. Modelled daily methane fluxes separated by transport pathway for seven sites using the overall best parameter set. Observations plotted as daily values (grey dots) and as monthly averages of daily values (black dots) are added for guidance.

temperature drops below the growing degree day minimum of $5{ }^{\circ} \mathrm{C}$, leaves of deciduous PFTs are shed. The air temperatures used to drive LPJ-WHyMe are realistic and the timing of the simulated leaf shedding in August corresponds to the observed leaf senescence in 2006 and 2007 (JackowiczKorczyński et al., 2010). However, for $\mathrm{CH}_{4}$ modelling, this sudden leaf shedding means that plant-mediated transport is cut off. In the real world methane can escape through plants even after the above ground parts have died back as tillers can still be a conduit for $\mathrm{CH}_{4}$ transport (Cronk and Fennessy, 2001) at least for a while after leaf senescence. This does not happen in the model so far and it may be necessary to include this process into a future version of LPJ-WHyMe.

Plant-mediated transport contributed $84.5 \%$ to total methane emissions and diffusion made up the rest (Table 8 and Fig. 6). Total annual simulated $\mathrm{CH}_{4}$ emissions were $8.9 \mathrm{~g} \mathrm{CH}_{4} \mathrm{~m}^{-2} \mathrm{a}^{-1}$ (Table 9), which is just over a third of the observed $24.5 \mathrm{~g} \mathrm{CH}_{4} \mathrm{~m}^{-2} \mathrm{a}^{-1}$ (Jackowicz-Korczyński et al., 2010).

\subsubsection{Ruoergai}

LPJ-WHyMe achieves the best results for the Ruoergai site, with RMSE values that are almost identical for both parameter combinations (Fig. 5). The availability of vegetation biomass data made a comparison between observed and modelled biomass possible for this site. LPJ-WHyMe models net primary production of $260 \mathrm{~g} \mathrm{C} \mathrm{m}^{-2} \mathrm{a}^{-1}$ (Table 6), which equates to $578 \mathrm{~g} \mathrm{~m}^{-2} \mathrm{a}^{-1}$ dry mass ( $45 \%$ carbon con- tent), in the middle of the observed net primary production range of $285-750 \mathrm{~g} \mathrm{~m}^{-2} \mathrm{a}^{-1}$ dry mass.

The seasonality of $\mathrm{CH}_{4}$ emissions is captured exceptionally well for this site, with a perfect interplay between the plant-mediated transport and diffusion process (Fig. 6). Ebullition is negligible and plant-mediated transport is responsible for $70.8 \%$ and diffusion for $28.8 \%$ of total emissions.

Ding et al. (2004) estimated mean methane fluxes for the two different Carex species at the Ruoergai site to be 2.06 and $3.88 \mathrm{mg} \mathrm{CH}_{4} \mathrm{~m}^{-2} \mathrm{~h}^{-1}$ and the average growing season length to be 165 days. This results in observed fluxes of 8.2 and $15.3 \mathrm{~g} \mathrm{CH}_{4} \mathrm{~m}^{-2}$ per growing season, which fits the modelled results of $14.20 \mathrm{~g} \mathrm{CH}_{4} \mathrm{~m}^{-2} \mathrm{a}^{-1}$ for the same period well (Table 9).

\section{Discussion}

LPJ-WHyMe has been designed for large-scale simulation of $\mathrm{CH}_{4}$ emissions from northern peatlands. The only gridcell specific inputs are climate data, $\mathrm{CO}_{2}$ concentration (one global number), and soil type (always "organic"). The climate data are from a standard, gridded data set. Using gridded climate data allows comprehensive coverage, but has the disadvantage for site-level predictions and data-model comparisons that the local climate may differ importantly from the grid-cell climate, especially in regions of high relief. The Stordalen (Abisko) site provides an example. Here the model 
underestimates emissions, and predicts an incorrect timing of emissions. In principle the mismatch might be due to our use of data from 2002 (the last year covered by CRU TS 2.1) to compare with flux measurements from 2006. However, data from CRU TS 3.0 (T. D. Mitchell, personal communication, 2010) extending through 2006 have recently become available. We have compared the 2002 and 2006 data and find little difference. Minimum, maximum and average temperatures for the Abisko grid cell were -15.6 vs. $-14.1,10.7$ vs. 10.0 , and -2.9 vs. $-3.0^{\circ} \mathrm{C}$, and total precipitation 603 vs. $564 \mathrm{~mm}$, for 2002 and 2006, respectively. The problem is more likely due to topographic heterogeneity not represented on the grid. Climate data for 2006 as directly measured at Stordalen are $-0.2{ }^{\circ} \mathrm{C}$ average temperature and $347 \mathrm{~mm}$ precipitation, i.e. the site is warmer and drier than the grid cell as represented in CRU. Too high winter precipitation leads to a thick snow cover that unrealistically delays soil thawing in spring (Fig. 5). In addition, ground water for the nearby lake flows through the mire at about $0.6 \mathrm{~m}$ depth and contributes energy to accelerate spring thawing (T. Christensen, personal communication, 2007), a feature which the model cannot represent. Finally, the low temperature bias delays spring warming. The combination of these site-specific biases leads to a strong delay and an underestimate of decomposition and methane production and emission in the model.

A separate topic related in part to the climate data is the model's inability to represent peak emission rates at five out of the seven sites (Fig. 5). The use of monthly rather than daily data is likely to be one cause. The way ebullition is modelled may also contribute. Ebullition is a complex process that depends on changes in atmospheric and hydrostatic pressure and the volumetric content of various gases (Tokida et al., 2007), which in turn depends on methane concentration and the density of nucleation sites for bubble formation (Vesala, 2010). This last factor is especially difficult to model. We opted for a simpler representation of ebullition compared to Wania et al. (2010) but in doing so we may have limited the model's ability to reproduce peak emissions.

Sensitivity analysis showed that the parameters most influencing $\mathrm{CH}_{4}$ emissions in the model are the ratio of $\mathrm{CH}_{4}$ to $\mathrm{CO}_{2}$ production, and the fraction of $\mathrm{O}_{2}$ used by methanotrophs. The ratio of $\mathrm{CH}_{4}$ to $\mathrm{CO}_{2}$ production has a linear effect on $\mathrm{CH}_{4}$ emission. A new experimental study has provided a range of 0.03 to 0.52 from six acrotelm cores from two UK peatlands under three temperature regimes (GallegoSala, 2008). The fraction of oxygen used by methanotrophs, $f_{\text {oxid }}$, also has a linear effect on $\mathrm{CH}_{4}$ emission. If more $\mathrm{O}_{2}$ is used to oxidise $\mathrm{CH}_{4}, \mathrm{CH}_{4}$ emission will be reduced while $\mathrm{CO}_{2}$ emission will be increased. A possible way to improve knowledge of $f_{\text {oxid }}$ would be to evaluate $\mathrm{CO}_{2}$ and $\mathrm{CH}_{4}$ emissions together while balancing the stoichiometry of $\mathrm{CO}_{2}, \mathrm{CH}_{4}$ and $\mathrm{O}_{2}$.

The parameter fitting exercise was used to find values that gave either the best site-specific results, or the best overall results, in comparison with observations. We adopted both approaches in order to highlight two points. One is to show how well the model can perform when tuned to local site conditions. The other is to illustrate the magnitude of error that results from the use of generic parameter values. The resulting increase in RMSE was slight at three of the sites, but much larger at the other sites: from 54\% (Michigan) to 137\% (Minnesota). The possible reasons for these discrepancies are beyond the scope of our analysis, but may relate to factors not considered in our modeling approach including (a) microtopography and (b) the biogeochemical distinction between bogs and fens, as discussed in Sect. 4.6 of Wania et al. (2009a).

\section{Conclusions}

This work represents the first attempt to fully couple a $\mathrm{CH}_{4}$ emission model into a DGVM framework suitable for largescale application. The use of generic climate data and parameter values allows large-scale simulation while unavoidably introducing some additional error compared to simulations driven by site-specific observations and/or using parameter values optimised for specific sites. The model could be run, for example, for countries to estimate peatland contributions to national greenhouse gas balance, or in palaeoclimate mode to explore causes of past variations in atmospheric $\mathrm{CH}_{4}$, or in future scenarios (Wania, 2007) to assess potential climate feedbacks involving $\mathrm{CH}_{4}$.

\section{Supplementary material related to this article is available online at: http://www.geosci-model-dev.net/3/565/2010/ gmd-3-565-2010-supplement.zip.}

Acknowledgements. The authors would like to thank Nathalie de Noblet-Ducoudré, Andy Ridgwell, Angela GallegoSala, Ed Hornibrook and Paul Miller for discussion of the model setup and the manuscript. The comments and suggestions by two anonymous reviewers, the editor and Timo Vesala have greatly improved this manuscript. We would also like to acknowledge Cynthia A. Brewer for the provision of Colorbrewer (http://www.colorbrewer2.org). RW was sponsored by a studentship of the Department of Earth Sciences, University of Bristol, by the EU-Project HYMN (GOCE-037048) and by an NSERC Accelerator grant (34940-27346). IR was supported by a NERC e-Science studentship (NER/S/G/2005/13913).

Edited by: A. Ridgwell

\section{References}

Alm, J., Saarnio, S., Nykanen, H., Silvola, J., and Martikainen, P. J.: Winter $\mathrm{CO}_{2}, \mathrm{CH}_{4}$ and $\mathrm{N}_{2} \mathrm{O}$ fluxes on some natural and drained boreal peatlands, Biogeochem., 44, 163-186, 1999. 
Aselman, I. and Crutzen, P. J.: Global distribution of natural freshwater wetlands and rice paddies, and their net primary productivity, seasonality and possible methane emissions, J. Atmos. Chem., 8, 307-358, 1989.

Benstead, J. and Lloyd, D.: Spatial and temporal variations of dissolved gases $\left(\mathrm{CH}_{4}, \mathrm{CO}_{2}\right.$, and $\left.\mathrm{O}_{2}\right)$ in peat cores, Microbial Ecol., 31, 57-66, 1996.

Bernard, J. M. and Fiala, K.: Distribution and standing crop of living and dead roots in three wetland Carex species, Bull. Torrey Bot. Club, 113, 1-5, 1986.

Broecker, W. S. and Peng, T.-H.: Gas exchange rates between air and sea, Tellus, 26, 21-35, 1974.

Bubier, J. L., Crill, P. M., Varner, R. K., and Moore, T. R.: BOREAS TGB-01/TGB-03 $\mathrm{CH}_{4}$ chamber flux data: NSA Fen. Data set. Available online [http://www.daac.ornl.gov] from Oak Ridge National Laboratory Distributed Archive Center, Tech. rep., Oak Ridge, Tennessee, USA, 1998.

Buytaert, W., Celleri, R., Bievre, B. D., Cisneros, F., Wyseure, G., Deckers, J., and Hofstede, R.: Human impact on the hydrology of the Andean páramos, Earth-Sci. Rev., 79, 53-72, 2006.

Camill, P., Lynch, J. A., Clark, J. S., Adams, J. B., and Jordan, B.: Changes in biomass, aboveground net primary production, and peat accumulation following permafrost thaw in the boreal peatlands of Manitoba, Canada, Ecosystems, 4, 461-478, 2001.

Cao, M. K., Marshall, S., and Gregson, K.: Global carbon exchange and methane emissions from natural wetlands: Application of a process-based model, J. Geophys. Res., 101, 14399-14414, 1996.

Chanton, J. P., Bauer, J. E., Glaser, P. A., Siegel, D. I., Kelley, C. A., Tyler, S. C., Romanowicz, E. H., and Lazrus, A.: Radiocarbon evidence for the substrates supporting methane formation within northern Minnesota peatlands, Geochim. Cosmochim. Acta, 59, 3663-3668, 1995.

Chen, Y. H. and Prinn, R. G.: Estimation of atmospheric methane emissions between 1996 and 2001 using a three-dimensional global chemical transport model, J. Geophys. Res., 111, D10307, doi:10.1029/2005JD006058, 2006.

Christensen, J. H., Hewitson, B., Busuioc, A., Chen, A., Gao, X., Held, I., Jones, R., Kolli, R. K., Kwon, W.-T., Laprise, R., Rueda, V. M., Mearns, L., Menéndez, C. G., Räisänen, J., Rinke, A., Sarr, A., and Whetton, P.: Regional climate projections, in: Solomon et al. (2007), chap. 11, pp. 847-940, 2007.

Christensen, T. R., Johansson, T., Åkerman, H. J., Mastepanov, M., Malmer, N., Friborg, T., Crill, P., and Svensson, B. H.: Thawing sub-arctic permafrost: Effects on vegetation and methane emissions, Geophys. Res. Lett., 31, L04501, doi:10.1029/2003GL018680, 2004.

Cole, J. J. and Caraco, N. F.: Atmospheric exchange of carbon dioxide in a low-wind oligotrophic lake measured by the addition of $\mathrm{SF}_{6}$, Limnol. Oceanogr., 43, 647-656, 1998.

Cronk, J. K. and Fennessy, M. S.: Wetland Plants: Biology and Ecology, CRC Press LLC, 2001.

Denman, K. L., Brasseur, G., Chidthaisong, A., Ciais, P., Cox, P. M., Dickinson, R. E., Hauglustaine, D., Heinze, C., Holland, E., Jacob, D., Lohmann, U., Rmachandran, S., da Silva Dias, P. L., Wofsy, S. C., and Zhang, X.: Couplings between changes in the climate system and biogeochemistry, in: Solomon et al. (2007), chap. 7, pp. 499-588, 2007.

Ding, W. X., Cai, Z. C., and Wang, D. X.: Preliminary budget of methane emissions from natural wetlands in China, Atmos. Environ., 38, 751-759, 2004.

Dise, N. B.: Methane emission from Minnesota peatlands: spatial and seasonal variability, Global Biogeochem. Cycles, 7, 123142, 1993.

Dise, N. B., Gorham, E., and Verry, E. S.: Environmental factors controlling methane emissions from peatlands in Northern Minnesota, J. Geophys. Res., 98, 10 583-10 594, 1993.

Etheridge, D. M., Steele, L. P., Langenfelds, R. L., Francey, R. J., Barnola, J. M., and Morgan, V. I.: Natural and anthropogenic changes in atmospheric $\mathrm{CO}_{2}$ over the last 1000 years from air in Antarctic ice and firn, J. Geophys. Res., 101, 4115-4128, 1996.

Forbrich, I., Wania, R., Kutzbach, L., Saarnio, S., Schäfer, C., and Wilmking, M.: Spatio-temporal dynamics of peatland methane emissions with regard to ecosystem modelling (LPJ-WHyMe), Tellus B, to be submitted, 2010.

Gallego-Sala, A. V.: Temperature effects on trace gas production and uptake in aerobic and anaerobic soils, Ph.D. thesis, University of Bristol, 2008.

Gerten, D., Schaphoff, S., Haberlandt, U., Lucht, W., and Sitch, S.: Terrestrial vegetation and water balance - hydrological evaluation of a dynamic global vegetation model, J. Hydrol., 286, 249-270, 2004.

Gower, S. T., Krankina, O., Olson, R. J., Apps, M., Linder, S., and Wang, C.: Net primary production and carbon allocation patterns of boreal forest ecosystems, Ecol. Appl., 11, 1395-1411, 2001.

Granberg, G., Ottosson-Lofvenius, M., Grip, H., Sundh, I., and Nilsson, M.: Effect of climatic variability from 1980 to 1997 on simulated methane emission from a boreal mixed mire in northern Sweden, Global Biogeochem. Cycles, 15, 977-991, 2001a.

Granberg, G., Svensson, I. S. B. H., and Nilsson, M.: Effects of temperature, and nitrogen and sulfur deposition, on methane emission from a boreal mire, Ecology, 82, 1982-1998, 2001 b.

Hanson, R. S. and Hanson, T. E.: Methanotrophic bacteria, Microbiol. Rev., 60, 439-471, 1996.

Iiyama, I. and Hasegawa, S.: Gas diffusion coefficient of undisturbed peat soils, Soil Sci. Plant Nutr., 51, 431-435, 2005.

Ingram, H. A. P.: Soil layers in mires - function and terminology, J. Soil Sci., 29, 224-227, 1978.

Jackowicz-Korczyński, M., Christensen, T. R., Bäckstrand, K., Crill, P., Friborg, T., Mastepanov, M., and Ström, L.: Annual cycles of methane emission from a subarctic peatland, J. Geophys. Res., 115, doi:10.1029/2008JG000913, 2010.

Jähne, B., Heinz, G., and Dietrich, W.: Measurement of the diffusion coefficients of sparingly soluble gases in water, J. Geophys. Res., 92, 10767-10776, 1987.

Johansson, T., Malmer, N., Crill, P. M., Friborg, T., Åkerman, J. H., Mastepanov, M., and Christensen, T. R.: Decadal vegetation changes in a northern peatland, greenhouse gas fluxes and net radiative forcing, Glob. Change Biol., 12, 1-18, doi:10.1111/j.1365-2486.2006.01267.x, 2006.

Joiner, D. W., Lafleur, P. M., McCaughey, J. H., and Bartlett, P. A.: Interannual variability in carbon dioxide exchanges at a boreal wetland in the BOREAS northern study area, J. Geophys. Res., 104, 27663-27672, 1999.

Keeling, C. D. and Whorf, T. P.: Atmospheric $\mathrm{CO}_{2}$ records from sites in the SIO air sampling network. In Trends: A compendium of data on global change, digital data, http://cdiac.esd.ornl.gov/ trends/co2/sio-mlo.htm, 2005. 
Lähteenoja, O., Ruokolainen, K., Schulman, L., and Oinonen, M.: Amazonian peatlands: an ignored $\mathrm{C}$ sink and potential source, Global Change Biol., 15, 2311-2320, doi:10.1111/j.13652486.2009.01920.x, 2009.

Lerman, A.: Geochemical processes: Water and sediment environments, John Wiley \& Sons, New York, 1979.

Lloyd, J. and Taylor, J. A.: On the temperature dependence of soil respiration, Funct. Ecol., 8, 315-323, 1994.

Maltby, E. and Immirzi, P.: Carbon dynamics in peatlands and other wetland soils: Regional and global perspectives, Chemosphere, 27, 999-1023, 1993.

Matthews, E. and Fung, I. Y.: Methane emission from natural wetlands: Global distribution, area, and environmental characteristics of sources, Global Biogeochem. Cycles, 1, 61-86, 1987.

McGillis, W. R., Dacey, J. W. H., Frew, N. M., Bock, E. J., and Nelson, R. K.: Water-air flux of dimethylsulfide, J. Geophys. Res., 105, 1187-1193, 2000.

Meehl, G. A., Stocker, T. F., Collins, W. D., Friedlingstein, P., Gaye, A. T., Gregory, J. M., Kitoh, A., Knutti, R., Murphy, J. M., Noda, A., Raper, S. C. B., Watterson, I. G., Weaver, A. J., and Zhao, Z.-C.: Global climate projections, in: Solomon et al. (2007), chap. 10, pp. 747-846, 2007.

Millington, R. J. and Quirk, J. P.: Permeability of porous solids, Trans. Faraday Soc., 57, 1200-1207, 1961.

Mitchell, T. D. and Jones, P. D.: An improved method of constructing a database of monthly climate observations and associated high-resolution grids, Int. J. Climatol., 25, 693-712, 2005.

Moldrup, P., Oleson, T., Yoshikawa, S., Komatsu, T., and Rolston, D.: Three-Porosity Model for predicting the gas diffusion coefficient in undisturbed soil, Soil Sci. Soc. Am. J., 68, 750-759, 2004.

Moore, T. R. and Dalva, M.: Influence of temperature and water table position on carbon dioxide and methane emissions from laboratory columns of peatland soils, Eur. J. Soil Sci., 44, 651664, 1993.

Moore, T. R. and Knowles, R.: Methane emissions from fen, bog and swamp peatlands in Quebec, Biogeochem., 11, 45-61, 1990.

Page, S., Rieley, J. O., and Banks, C. J.: Global and regional importance of the tropical peatland carbon pool, Global Change Biol., p. Early View article, doi:10.1111/j.1365-2486.2010.02279.x, 2010.

Potter, C. S., Davidson, E. A., and Verchot, L. V.: Estimation of global biogeochemical controls and seasonality in soil methane consumption, Chemosphere, 32, 2219-2246, 1996.

Riera, J. L., Schindler, J. E., and Kratz, T. K.: Seasonal dynamics of carbon dioxide and methane in two clear-water lakes and two bog lakes in northern Wisconsin, USA, Can. J. Fish. Aquat. Sci., 56, 265-274, 1999.

Saarinen, T.: Biomass and production of two vascular plants in a boreal mesotrophic fen, Can. J. Bot., 74, 934-938, 1996.

Saarnio, S., Alm, J., Silvola, J., Lohila, A., Nykänen, H., and Martikainen, P. J.: Seasonal variation in $\mathrm{CH}_{4}$ emissions and production and oxidation potentials at microsites on an oligotrophic pine fen, Oecologia, 110, 414-422, 1997.

Sander, R.: Compilation of Henry's Law Constants for inorganic and organic species of potential importance in environmental chemistry, Tech. Rep. Version 3, MPI Mainz, Air Chemistry Department, Max-Planck Institute of Chemistry, 1999.

Schimel, J. P.: Plant transport and methane production as controls on methane flux from arctic wet meadow tundra, Biogeochem., 28, 183-200, 1995.

Segers, R.: Methane production and methane consumption: a review of processes underlying wetland methane fluxes, Biogeochem., 41, 23-51, 1998.

Segers, R. and Leffelaar, P.: On explaining methane fluxes from weather, soil and vegetation data via the underlying processes, in: Northern peatlands in global climate change, edited by Laiho, R., Laine, J., and Vasander, H., pp. 226-241, The Academy of Finland, Helsinki, 1996.

Shannon, R. D. and White, J. R.: A three-year study of controls on methane emissions from two Michigan peatlands, Biogeochem., 27, 35-60, 1994.

Shannon, R. D., White, J. R., Lawson, J. E., and Gilmour, B. S.: Methane efflux from emergent vegetation in peatlands, J. Ecol., 84, 239-246, 1996.

Sitch, S., Smith, B., Prentice, I. C., Arneth, A., Bondeau, A., Cramer, W., Kaplan, J. O., Levis, S., Lucht, W., Sykes, M. T., Thonicke, K., and Venevsky, S.: Evaluation of ecosystem dynamics, plant geography and terrestrial carbon cycling in the LPJ dynamic global vegetation model, Glob. Change Biol., 9, 161$185,2003$.

Solomon, S., Qin, D., Manning, M., Chen, Z., Marquis, M., Averyt, K. B., Tignor, M., and Miller, H. L., Climate change 2007: The physical science basis, Contribution of Working Group I to the Fourth Assessment Report of the Intergovernmental Panel on Climate Change, Cambridge University Press, Cambridge, United Kingdom and New York, NY, USA, 2007.

Ström, L., Mastepanov, M., and Christensen, T. R.: Species-specific effects of vascular plants on carbon turnover and methane emissions from wetlands, Biogeochem., 75, 65-82, 2005.

Svensson, B. H.: Different temperature optima for methane formation when enrichments from acid peat are supplemented with acetate or hydrogen, Appl. Environ. Microbiol., 48, 389-394, 1984.

Tokida, T., Miyazaki, T., Mizoguchi, M., Nagata, O., Takakai, F., Kagemoto, A., and Hatano, R.: Falling atmospheric pressure as a trigger for methane ebullition from peatland, Global Biogeochem. Cycles, 21, GB2003, doi:10.1029/2006GB002790, 2007.

Vesala, T.: Interactive comment on "Implementation and evaluation of a new methane model within a dynamic global vegetation model: LPJ-WHyMe v1.3" by R. Wania et al., Geosci. Model Dev. Discuss., 3, C13, 2010.

Vogels, G. D., Keltjens, J. T., and van der Drift, C.: Biochemistry of methane production, in: Biology of anaerobic microorganisms, edited by Zehnder, A. J. B., pp. 707-770, John Wiley \& Sons, New York, 1988.

Walter, B. P. and Heimann, M.: A process-based, climate-sensitive model to derive methane emissions from natural wetlands: Application to five wetland sites, sensitivity to model parameters, and climate, Global Biogeochem. Cycles, 14, 745-765, 2000.

Walter, B. P., Heimann, M., and Matthews, E.: Modeling modern methane emissions from natural wetlands 1 . Model description and results, J. Geophys. Res., 106, 34189-34206, 2001.

Wania, R.: Modelling northern peatland land surface processes, vegetation dynamics and methane emissions, $\mathrm{PhD}$ thesis, University of Bristol, 2007.

Wania, R., Ross, I., and Prentice, I. C.: Integrating peatlands and permafrost into a dynamic global vegetation model: I. Evalua- 
tion and sensitivity of physical land surface processes, Global Biogeochem. Cycles, 23, GB3014, doi:10.1029/2008GB003412, 2009a.

Wania, R., Ross, I., and Prentice, I. C.: Integrating peatlands and permafrost into a dynamic global vegetation model: II. Evaluation and sensitivity of vegetation and carbon cycle processes, Global Biogeochem. Cycles, 23, GB3015, doi:10.1029/2008GB003413, 2009b.

Wania, R., Ross, I., and Prentice, I. C.: Implementation and evaluation of a new methane model within a dynamic global vegetation model: LPJ-WHyMe v1.3, Geosci. Model Dev. Discuss., 3, 159, doi:10.5194/gmdd-3-1-2010, 2010.

Wanninkhof, R.: Relationship between wind-speed and gasexchange over the ocean, J. Geophys. Res., 97, 7373-7382, 1992.

Weltzin, J. F., Pastor, J., Harth, C., Bridgham, S. D., Updegraff, K., and Chapin, C. T.: Response of bog and fen plant communities to warming and water-table manipulations, Ecology, 81, 34643478, 2000.
Whitman, W. B., Bowen, T. L., and Boone, D. R.: The methanogenic bacteria, in: The prokaryotes, a handbook on the biology of bacteria: Ecophysiology, isolation, identification, applications, edited by Ballows, A., Trüper, H. G., Dworkin, M., Harder, W., and Schleifer, K.-H., pp. 719-767, Springer-Verlag, New York, 2nd edn., 1992.

Yamamoto, S., Alcauskas, J. B., and Crozier, T. E.: Solubility of methane in distilled water and seawater, J. Chem. Eng. Data, 21, 78-80, 1976.

Zhuang, Q., Melillo, J. M., Kicklighter, D. W., Prinn, R. G., McGuire, A. D., Steudler, P. A., Felzer, B. S., and $\mathrm{Hu}$ S.: Methane fluxes between terrestrial ecosystems and the atmosphere at northern high latitudes during the past century: A retrospective analysis with a process-based biogeochemistry model, Global Biogeochem. Cycles, 18, GB3010, doi:10.1029/2004GB002239, 2004. 